\title{
Investigating the Reasons of Difficulty Understanding of Students in Special Relativity Topics
}

\author{
Hasan Şahin KIZILCIK*, Pervin ÜNLÜ YAVAŞ
}

Gazi Üniversitesi, Gazi Eğitim Fakültesi, Ankara/Türkiye

\begin{tabular}{l}
\hline Article Info \\
\hline DOI: $10.14812 /$ cuefd. 297883 \\
\hline \\
\\
\hline Keywords: \\
Special relativity, \\
Likert test, \\
Difficulty understanding. \\
\hline
\end{tabular}

\begin{abstract}
Special relativity has been started to be taught in high schools in addition to universities. Moreover, it attracts the attention of scientifically literate individuals. The purpose of this study is to determine high school and university students' levels of difficulty understanding of special relativity. Furthermore, if it made a difference according to gender or educational level was also searched. In our previous study, which formed a basis for this research, the students' opinions about difficulty understanding were determined by the interviews. The opinions obtained from the previous research were compiled and a Likert test with 5 option was prepared. This scale was applied to 691 student (446 science teacher candidates and 245 high school students). When the data obtained from the scale with 23 items applied was analyzed, it consisted of three factors. These factors are the perception of the topic, mathematical difficulties and the teaching methods difficulties. According to the general results, the students think that this topic is easy as much as they think it is difficult. High school students remarked that they had more difficulties than the university students and women remarked that they had more difficulties than men from some points of view.
\end{abstract}

\begin{tabular}{|c|c|}
\hline \multicolumn{2}{|c|}{$\begin{array}{c}\text { Öğrencilerin Özel Görelilik Konularında Zorlanma Nedenlerinin } \\
\text { Araştırılması }\end{array}$} \\
\hline Makale Bilgisi & Öz \\
\hline DOI: 10.14812/cuefd.297883 & $\begin{array}{l}\text { Özel görelilik, son yıllarda üniversite seviyesine ek olarak lisede de öğretilmeye } \\
\text { başlanan bir konudur. Ayrıca fen okur-yazarı bireyler tarafından da ilgi görmektedir. Bu } \\
\text { araştırmanın amacı lise ve üniversite öğrencilerinin özel görelilik konusunda daha } \\
\text { önceden belirlenmiş olan zorlanma nedenlerine katılma derecelerini belirlemektir. } \\
\text { Ayrıca zorlanma nedenlerine katılımın eğitim düzeyi ve cinsiyete göre farklılık } \\
\text { oluşturup oluşturmadığı araştırılmışır. Bu araştırmaya temel oluşturan önceki } \\
\text { çalışmada, öğrenciler ile görüşmeler yoluyla, özel görelilikte zorlanma sebepleri } \\
\text { hakkında görüşleri belirlenmişti. Önceki araştırmadan elde edilen görüşler derlenerek } 5 \\
\text { dereceli Likert bir ölçek hazırlanmıştır. Bu ölçek, özel görelilik konularını içeren ders } \\
\text { almış olan } 446 \text { fen bilgisi öğretmen adayına ve } 245 \text { lise öğrencisine olmak üzere, } \\
\text { toplam } 691 \text { kişiye uygulanmıştır. Uygulanan } 23 \text { maddelik ölçeğin verileri analiz } \\
\text { edildiğinde üç faktörden oluştuğu belirlenmiştir. Bunlar, konuya yönelik algı, } \\
\text { matematiksel nedenlerden kaynaklanan zorluklar ve öğretim yönteminden } \\
\text { kaynaklanan zorluklardır. Araştırmanın genel sonuçlarına göre, öğrenciler bu konuyu }\end{array}$ \\
\hline $\begin{array}{l}\text { Anahtar Kelimeler: } \\
\text { Özel görelilik, } \\
\text { Likert ölçek, } \\
\text { Anlama zorlukları. }\end{array}$ & $\begin{array}{l}\text { zor olduğu kadar kolay olduğunu da düşünmektedir. Ölçek maddelerinin faktörlere } \\
\text { göre ayrıntıı incelenmesi zorluklara katııı hakkında daha ayrıntılı bilgiler vermektedir. } \\
\text { Her bir maddede yer alan ifadenin zor veya kolay olarak öğrenciler tarafından } \\
\text { nitelendirilmesi; cinsiyete, öğrenim düzeyine bağlı olabileceği gibi, bunlardan bağıısız } \\
\text { olarak da değişebilmektedir. Lise öğrencileri, üniversite öğrencilerine göre, kadınlar ise } \\
\text { erkeklere göre bazı açılardan daha çok zorlandıklarını belirtmişlerdir. }\end{array}$ \\
\hline
\end{tabular}

*Author: hskizilcik@gazi.edu.tr 


\section{Introduction}

Einstein's Theory of Relativity radically changed our opinions about the physical world. Our concepts of absolute time and space until the 20th century changed and the concept of spacetime took their place. Teaching the theory of relativity has become obligatory with this change. The Theory of Relativity consists of concepts which are difficult to be taught and learnt. For example, Penrose (1959), Terrell (1959) and Weisskopf (1960) remarked that a photograph of an object which moves relatively is different from what Lorentz's contraction anticipated. Diessler (2005) indicated the importance of emphasizing on the words such as "measurement" and "observer" while explaining the time dilation and length contraction in teaching special relativity and he recommended the use of words such as "seeing" for the length contraction. The reasons are the optical effects originating from the different parts of the object being at different distances for the observer. What makes Einstein's theory of relativity so deep is the fact that the length really contracts and the time really dilates. It is not only a matter of appearance. There are studies in which the exercises to be done in the classroom to indicate this circumstance known as Terrell's effect in order to indicate that Lorentz's contraction is different from the photographic appearance of an object moving relatively (Burke va Strode, 1991).

Most of the difficulties in understanding the theory of relativity originate from the relative effects' not being a part of daily experiences and their looking like as if conflicting with daily experiences. Moreover, it is not possible to directly observe the relative effects by show experiments (Kraus, 2008). Special relativity has bizarre effects outwardly and it is mainly about the situations outside the daily experiences. Use of thought experiments in teaching the theory of relativity enable the students to recognize the situations beyond daily experiences. It will make understanding the laws of relativity easy for them (VelentzasveHalkia, 2013). In relation to that, Al-Khalili (2003) claims that using the idea of time travelling in teaching the relativity will give an opportunity in revealing the imagination and understanding the nature of spacetime, contrary to many. He expresses that there are good examples to be used in emphasizing the interesting features of Special Relativity. Cacioppo and Gangopadhyaya (2012) who drew attention to the importance of Special Relativity presented two thought experiments about length contraction for university students and he remarked that they would provide the students a deep understanding about the topic. Simulations and computer games in which relative effects are experienced virtually are used in coming over the deficiencies about daily experience. Wegener, McIntyre, McGrath, Savage and Williamson (2012) successfully used a teaching package in which virtual reality similar to a game simulating a World conforming to special relative physics. Kortemeyer, Fish, Hacker, Kienle, Kobylarek, Sigler, Wierenga, Cheu, Kim, Sherin, Sidhu and Tan (2013) developed a computer games to be used in teaching the students special relativity. Savage, Searle and McCalman (2007) state that the students will discover the relativity of the contraction of length and simultaneousness with a computer program which provides the opportunity of movement in a simulated World where movement at relative speeds exist. Carr and Bossomaier (2011) remarked that there was an improvement in the students' motivations and their comprehending the topic in an application they made placing the special relativity effects. Sherin, Cheu, Tan and Kortemeyer (2016) remarked that the abstract concept and topics of special relaivity would provide first hand experiences thanks to a computer game in which the effects of special relativity could be experienced. They reported that the computer game they developed drew interest at the internet environment and there were positive feedbacks. Belloni, Christian and Dancy (2004) introduced the Physlet based exercises to be useful in visualizing the abstract concepts of special relativity.

Another difficulty in teaching relativity is the classical physics-relative physics paradigm change's not being perceived by the students. According to Arriassecq and Greca (2012), students cannot understand the difference between the classical physics and the concepts special relativity contains. In his study, Gim (2016) searched how the theory of special relativity taught at high schools in South Korea took place in textbooks and he remarks that the theory does not emphasize on its revolutionary aspect in terms of physics theories. In his article, Ireson (1996) remarks that the traditional way in teaching special relativity is to mention the Michelson-Morley experiment's results about the speed of light, to propound 
the need for frames of reference and to define the two prinicples of special relativity. Instead, he recommends to expose the students to the situation in which they will recognize its deficiencies and teach the special relativity by helping them to find a solution for the problem, starting from the Newtonian and Aristotelian worldview. Dimitriadi and Halkia (2012) state that the students deepen the idea of absolute movement they learned in classical mechanics and it caused the students to include the relativity in classical physics in teaching relativity. It was according to the results of their research about the high school students' processes of learning the theory of special relativity. The study conducted by Pietrocola and Zylberztajn (1999) indicated that the students did not feel the need to use the interpretative structures except classical mechanics and common sense in the problems about special relativity. According to Arriassecq and Greca (2012), use of the historical and epistemological context has positive effects in making the students understand the change between classical physics and relative physics. In addition, in the qualitative study he conducted on a documentary containing the theory of relativity, SeçkinKapucu (2016) remarked that the documentary could be used in teaching some themes and concepts of the nature of the science. Moreover, it was said that the use of this kind of documentaries in education will increase the students' motivations for learning. VillaniveArruda (1998) state that the experimental results and applications which can be interpreted with Lorentz's transformation equations and Einstein's equations should be more focused on and it is important to emphasize the differences between the classical and modern ideas in teaching special relativity. They express the necessity of a teaching environment where they will recognize the existence of the conceptual change in the World of science and its basic features.

One of the reasons why relativity is difficult to learn is the students' deficiency in classical physics. Scherr, Shaffer veVokos (2001) searched the students' conceptual and logical difficulties about the concept of time in relativity and the role of the frames of reference. The results indicate that the students experience serious difficulties in the topics of the relativity of the simultaneity and the role of the observer in the inertial reference systems. The students make a conceptual framework where absolute simultaneity and the relativity of simultaneity exist simultaneously. It was seen that even the students at advanced levels were unsuccessful in interpreting the effects of special relativity in understanding the physical World. The students remark that the reason underlying these failures of theirs is the deficiency in their understanding the basic topics.

The Theory of Relativity is a topic which is interesting and intriguing beside its being difficult to learn. Angell, Guttersrud, Henriksen and Isnes (2004) searched the opinions of both teachers and students about physics and physics education in Norway. According to this study, relativity is the second most interesting one among the other physics topics. According to Ogborn (2005), the students are quite enthusiastic when they start to learn relativity but they lose this enthusiasm of theirs when they face Lorentz's transformation and some complicated algebraic operations. According to the results of the study conducted by Angell (2004), teachers complain about the students' weak mathematical skills and the students do not regard mathematics as an important problem in physics lessons.

Arriassecq and Greca (2007) studied high school and university textbooks in Argentina in terms of content and they drew attention to the inadequacy of the teachers' course materials about the theory of special relativity started to be taught at high schools in terms of contextual perspective. He remarked that preparing contextually suitable and motivating materials in teaching special relativity will be effective in enabling the students' learning meaningfully. Smith (2011) emphasized on the benefits of visualization for the students to understand the special relativity concepts better. He remarked that the graphics and simple calculations used for visualizing an electric dipol moving with relative speeds in an electromagnetic area indicated the phenomenna such as the light's stability within inertial frames of reference and Doppler effect. Ogborn (2005) recommended a teaching material which teachers could utilise in teaching special relativity, consisting of four steps and the teacher could stop at the stage he wanted according to his choice. He warned the teachers about teaching less could achieve more in terms of teaching the essence of relativistic thought. Scherr, Shaffer and Vokos (2002) made a teaching material which improved the students' understanding special relativity concepts, the relativity of 401 
simultaneity and the role of the observer in the inertial frames of reference. They remark that this material improves the students' skills of recognizing and solving some of the classical paradoxes in special relativity. Guisasola, Solbes, Barragues, Morentin and Moreno (2009) reported that a visit to the exhibition prepared because of the first century of the theory of special relativity increased the students' knowledge about the theory of special relativity and their interest in it and it improved their comprehension of the theory. Increase was determined in the students' levels of knowledge about the speed of light, time and the reference system, mass and energy after the visit.

Recently, the importance attached to teaching this theory has increased and it has started to take place in high school physics teaching programs. The theory of special relativity is taught in the tenth year in the 2007 physics teaching program (MEB, 2007) and it was taught in the twelfth year with reduced mathematics in the 2013 physics teaching program (MEB, 2013). The theory is also taught in science teaching departments other than physics and physics teaching departments of universities. In parallel to the increasing interest about teaching relativity in Turkey, science teaching researches have increased in the recent years (Demir and Akarsu, 2014; DidişKörhasan and Özcan, 2015; Selçuk, 2011; Özcan, 2011; ÜnlüYavaş and Kızılcık, 2016; Yıldız, 2012).

Researches were made about the theory of relativity ususally with university students in Turkey. Selçuk (2011) determined the difficulties of the university students in the concepts of time, time dilation, length, mass and density within the theory of special relativity. Özcan (2011) analysed physics teachers' problem solving approaches about the theory of special relativity and he concluded that the participants' problem solving approaches were not scientifical and strategical. The results of the qualitative research made by Turgut, Gurbuz, Salar and Toman (2013) about teacher candidates' understanding the theory of special relativity propounds that the teacher candidates have problems in understanding and interpreting the concepts of special relativity. Moreover, mathematical difficulties are also seen about this topic. DidişKörhasan and Özcan (2015) remarked that university students had difficulties in using mathematical models in their problem solvings about special relativity. It was reported that mathematical difficulties and difficulties about transition from classical physics to relative physics became prominent in the qualitative study in which the ideas about the teacher candidates' reasons of having difficulties were searched (ÜnlüYavaş and Kızılcık, 2016). The study conducted by Demir and Akarsu (2014) with both high school and university students indicate that special relativity is one of the topics which the students found difficult among modern physics topic. In another research made with high school students, conceptual delusions about special relativity were searched (Korkmaz, AybekveÖrücü, 2016). Yıldız (2012) remarks that writing to learn activities make contributions to the teacher candidates' understanding the theory of special relativity.

In the studies in which the students' difficulties about relativity were researched, the difficulties were determined usually based on the students' answers to the questions about relativity. Although there are many studies in which the students' reasons of having difficulties in physics are researched, no studies in which the students were asked questions about the reasons of their having difficulties about relativity were found. Because of this reason, this research is different than the other researches in terms of determining the students' difficulties in relativity topics. In this research, a qualitative scale which was formed using the students' answers about the reasons of difficulties was utilised. The purpose of the research is to determine the high school and university students' frequency of the reasons of having difficulties about special relativity. Moreover, if any difference existed in the frequency of these reasons according to educational level or gender was also analysed.

\section{Method}

The research was started utilising the data from a qualitative atudy we conducted previously (ÜnlüYavaş\&Kızılcık, 2016). The previous study was conducted with 25 physics teacher candidates after teaching the special relativity topics. 


\section{Instrument}

The opinions of the participants about the easiness or difficulty of the topics of relativity in time, relativity in length, Lorentz's transformation equations, Lorentz's speed transformation equations, relative momentum and relative energy were determined with the interviews made. During the interviews, it was seen that the reasons for having difficulties were based on various reasons, the students' teaching methods, mathematical problems, problems experienced in transition from classical physics to relative physics foremost. We arranged the 28 opinions obtained from the qualitative analysis of these interviews and and we made them the items of a Likert type scale. Thus, we obtained a 5 point Likert scale in which the students could mark their levels of participation in the difficulty indicated in the items. The scoring of the scale was prepared to indicate the level of agreement between 5 and 1 . If the item was notifying an easiness the scoring was made making it reverse. In other words, contribution to the difficulty participation for each mentioned item became 5 points as the highest score and 1 point as the lowest score.

\section{Participiant}

We applied the mentioned scale to totally 961 people, 446 science techer candidates and 245 high school students, who took lessons containing special relativity topics. Our purpose here is to determine the commonness level of the difficulty reasons we determined in our previous study among the students. Definitive data about the sample were given in Table 1.

Table 1.

Definitive characteristics of the sample

\begin{tabular}{llc}
\hline Group & Subgroup & Number of students \\
\hline \multirow{2}{*}{ Education Level } & High school & 245 \\
\cline { 2 - 3 } & University & 446 \\
\hline \multirow{3}{*}{ Gender } & Female & 450 \\
\cline { 2 - 3 } & Male & 220 \\
\cline { 2 - 3 } & Unknown & 21 \\
\hline
\end{tabular}

Exploratory factor analysis was made with the data obtained. According to it, the common variances of the scale consisting of 28 items range between 0,399 and 0,634. 4 factors whose eigenvalue is higher than 1 explain the 50,637 \% of the total variance. However, when the cyclical items (1st, 8th, 9th, 20th and 28th items in the test of 28 items) were deleted, the scale indicated a structure with 3 factors. These three factors explain the $48,06 \%$ of the total variance. According to the test data consisting of the remaining 23 items, the first factor consists of the 1st, 2nd, 4th, 5th, 6th, 8th, 10th, 11th, 12th, 13th, 15 th, 19th, 20th and 23rd items. The second factor consists of the 3rd, 7th, 9th, 14th, 16th and 21st items. The third factors consists of the 17th, 18th and 22nd items. Generally, when the items forming the first factor were regarded, it is seen that they generally contain the student's perception of the topic, the second factor contains the instruction tecnique of the topics and the third factor contains the difficulties.

We analysed the data by statistical software. We found the reliability coefficent of the data we obtained as 0,91 . It was determined that the correlation between the items was generally high. According to this, it can be said that the internal validity of the scale is high.

We made comparisons between the descriptive analyses and subgroups. The Likert items' effect on difficulty was graded because the lowest difficulty level was 1 and the highest difficulty level was 5 . The degrees applied while evaluating the data are given in Table 2. 
Table 2.

Evaluation degrees of the data

\begin{tabular}{ll}
\hline Criterion & Its effect on difficulty \\
\hline $1.00-1.79$ & Very easy \\
\hline $1.80-2.59$ & Easy \\
\hline $2.60-3.39$ & Moderate \\
\hline $3.40-4.19$ & Difficult \\
\hline $4.20-5.00$ & Very difficult \\
\hline
\end{tabular}

We looked at the scores of each Likert type item to see into which ranges they could be included among the ranges we indicated in Table 2. We made comments according to it. Moreover, we analysed it to see if there was a significant difference according to educational levels or gender, utilising the independent sample t-test.

\section{Result}

Firstly, we made a descriptive analysis of the Likert scale. We found the dispersion of the students' in the 1-5 range according to difficulty grading taking the average of all of the items of the scale and we gave them in the graphic in Figure 1.

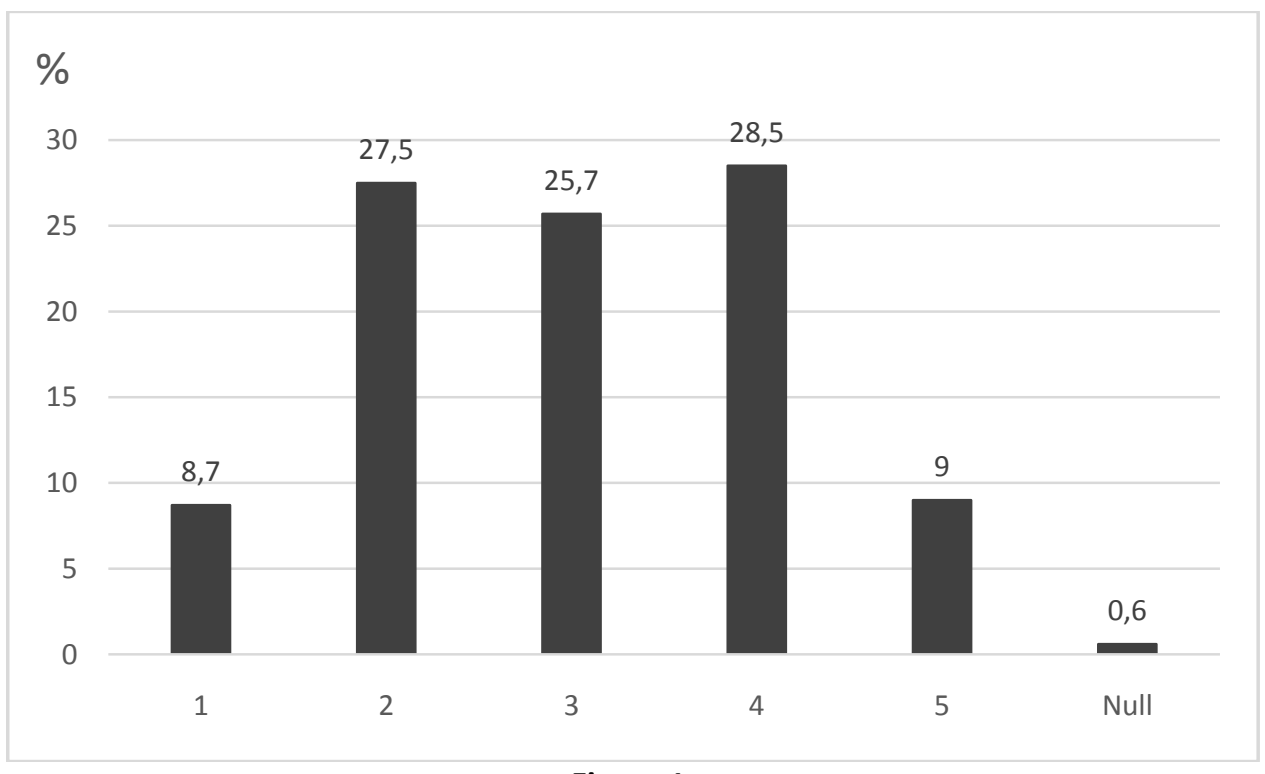

Figure 1.

Percentage dispersion of the difficulty level

According to Figure 1, the students marked the 2 nd, 3rd and 4th options most. When the " 3 " in the middle is based on according to the difficulty grading of the graphic, its having a dispersion which is almost symmetric indicates that the students think that the topic of general relativity is easy as much as they have difficulties in it. It is seen that no option's rate of being marked exceeds $30 \%$.

When the average scores of all items were calculated, it was seen that all of them had difficulty at middle level according to the criterion indicated in Table 2.

The item scores at middle levels does not give us much information in terms of the students' reasons of having difficulties. So, it will be useful to approach the items forming each factor together and making commentations according to it. 


\section{Analysis of the Data AccordingtotheFactors}

We remarked that the data of the Likert scale with 23 items applied consisted of three factors when they were wereanalysed. These factors were analysedseperately and they were presented in tables. The highest value determined in the graphic of the percentage dispersions of the difficulty level given in Figure 1 was 28,5\%. Because of this reason, 197 answers which made the 28,5\% of the total answers and the answers over it were marked as oblique and thick lines. This situation will make commenting easy.

The data from the first factor, the factor in which the perception about the topic mainly takes place are seen in Table 3.

Table 3.

Frequency dispersion of the answers given to the items in the first factor

\begin{tabular}{|c|c|c|c|c|c|c|c|c|}
\hline \multirow{2}{*}{$\begin{array}{c}\text { Item } \\
\text { No }\end{array}$} & \multirow{2}{*}{ Item } & \multicolumn{2}{|c|}{ VeryEasy $\leftarrow$} & \multicolumn{3}{|c|}{$\rightarrow$ VeryDiffucult } & \multirow{2}{*}{ Null } & \multirow[b]{2}{*}{$\begin{array}{l}\text { Avr. } \\
\text { Score }\end{array}$} \\
\hline & & 1 & 2 & 3 & 4 & 5 & & \\
\hline 1 & $\begin{array}{l}\text { It is difficult to understand the connections and } \\
\text { keep them in mind. }\end{array}$ & 40 & 172 & 124 & 274 & 77 & 4 & 3,26 Mod. \\
\hline 2 & $\begin{array}{l}\text { It is difficult because it requires too much effort } \\
\text { and time. }\end{array}$ & 49 & 186 & 159 & 228 & 67 & 2 & 3,11 Mod. \\
\hline 4 & It is difficult to interpret relativity. & 50 & 159 & 176 & 232 & 68 & 6 & 3,16 Mod. \\
\hline 5 & $\begin{array}{l}\text { It is difficult to understand why relativity is } \\
\text { needed. }\end{array}$ & 80 & 178 & 188 & 179 & 64 & 2 & 2,96 Mod. \\
\hline 6 & $\begin{array}{l}\text { Its being not a situation faced in daily life made it } \\
\text { difficult for me to understand. }\end{array}$ & 55 & 164 & 134 & 243 & 95 & - & 3,23 Mod. \\
\hline 8 & $\begin{array}{l}\text { The stage of transition from the quantities in } \\
\text { classical physics to the relative quantities caused } \\
\text { me to have difficulties. }\end{array}$ & 39 & 164 & 195 & 226 & 67 & - & 3,17 Mod. \\
\hline 10 & $\begin{array}{l}\text { I had difficulties because I had general } \\
\text { deficiencies in classical physics. }\end{array}$ & 43 & 160 & 155 & 250 & 80 & 3 & 3,24 Mod. \\
\hline 11 & $\begin{array}{l}\text { I had difficulties in associating classical and } \\
\text { relative concepts. }\end{array}$ & 43 & 167 & 182 & 232 & 61 & 6 & 3,15 Mod. \\
\hline 12 & $\begin{array}{l}\text { I had difficulties in distinguishing classical and } \\
\text { relative concepts. }\end{array}$ & 52 & 201 & 192 & 189 & 53 & 4 & 2,99 Mod. \\
\hline 13 & I found the topic difficult because it was abstract. & 60 & 165 & 157 & 224 & 79 & 6 & 3,14 Mod. \\
\hline 15 & I have prejudices about the topic's being difficult. & 60 & 158 & 182 & 200 & 82 & 9 & 3,13 Mod. \\
\hline 19 & $\begin{array}{l}\text { It is difficult to determine which quantity is } \\
\text { measured in which reference system. }\end{array}$ & 27 & 154 & 236 & 202 & 68 & 4 & 3,19 Mod. \\
\hline 20 & $\begin{array}{l}\text { Its having results contradictory to my reason / } \\
\text { anticipations made it difficult for me to } \\
\text { understand. }\end{array}$ & 53 & 181 & 189 & 203 & 60 & 5 & 3,05 Mod. \\
\hline \multirow[t]{2}{*}{23} & $\begin{array}{l}\text { It is difficult to understand because it requires a } \\
\text { new perception and philosophy. }\end{array}$ & 51 & 191 & 173 & 225 & 50 & 1 & 3,05 Mod. \\
\hline & Averages & s 50,1 & 171,4 & 174, & 221,9 & 69,4 & 4,3 & 3,13 Mod. \\
\hline
\end{tabular}

When the Table 3 is analysed and the general average of the first factor consisting of the items about the students' perception about the topic is regarded, it can be said that there is a difficulty in the "moderate" level. However, it is seen that the answers conglomerate towards "4" which indicates difficulty in the fivefold grading, except two items. It is seen that most of the items here are about the students' difficulties in perceiving the differences between classical physics and relative physics, 
adapting themselves to a new understanding and adapting it to their daily experiences and reason. Besides, it was determined that there were items to be associated with mathematics even if they were few. Conglomeration was seen in the items about the difficulties caused by the classical physics relative physics paradigm change (Items $4,8,11,23$ ) and in the items about requiring extra effort, time and endeavor (Items 3, 8). It was also seen in the item about prejudices about the difficulty of the topics (Madde 15) at high difficulty level. Moreover, problems because of classical physics (Item 10), problems about the association of the topic with daily life and its being regarded as an abstract topic (Items 6,13 ) were also indicated as difficulty reasons.

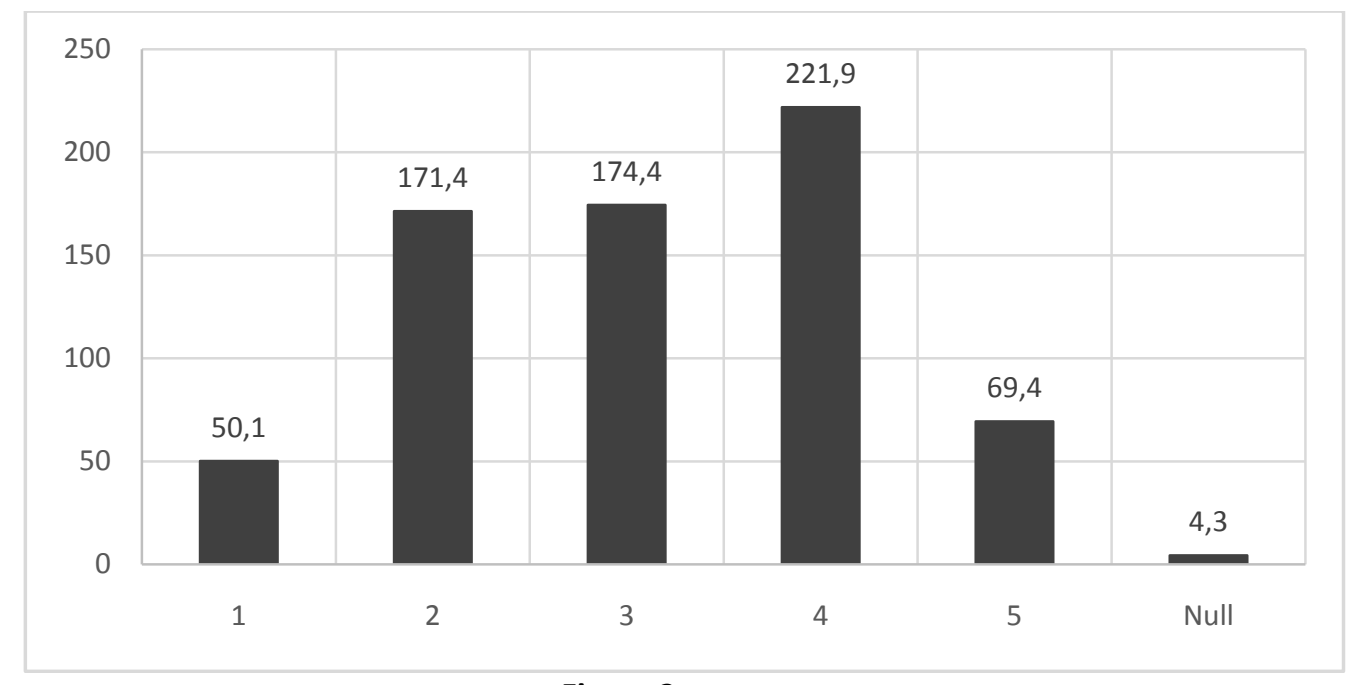

Figure 2.

Dispersion of the average difficulty level for the first factor

As it is seen in Figure 2, the general difficulty levels of the students about the first factor are inclined to " 4 " in the fivefold grading. In other words, even if the averages indicate a difficulty at "moderate" level, it can be said that there is an inclination to "difficult" in this factor.

Table 4.

Frequency dispersion of the answers given to the items in the second

\begin{tabular}{|c|c|c|c|c|c|c|c|c|}
\hline \multirow{2}{*}{\multicolumn{2}{|c|}{ Item Noltem }} & \multicolumn{2}{|c|}{ VeryEasy $\leftarrow$} & \multicolumn{5}{|c|}{$\begin{array}{r}\rightarrow \\
\text { VeryDiffucult }\end{array}$} \\
\hline & & \multirow{2}{*}{$\frac{1}{85}$} & \multirow{2}{*}{$\begin{array}{c}2 \\
236\end{array}$} & \multirow{2}{*}{$\frac{3}{202}$} & \multirow{2}{*}{$\begin{array}{c}4 \\
136\end{array}$} & \multirow{2}{*}{$\frac{5}{30}$} & \multirow{2}{*}{$\begin{array}{c}\text { Null } \\
2\end{array}$} & \multirow{2}{*}{$\begin{array}{c}\text { Avr. } \\
\text { Score Range } \\
\text { 2,70 Mod. }\end{array}$} \\
\hline 3 & $\begin{array}{l}\text { It is easy because the relative quantities are } \\
\text { more logical than the classical ones. }\end{array}$ & & & & & & & \\
\hline 7 & $\begin{array}{l}\text { The documentaries / animations I watched } \\
\text { made it easy for me to understand. }\end{array}$ & 133 & 265 & 135 & 102 & 50 & 6 & 2,52 Easy \\
\hline 9 & $\begin{array}{l}\text { It was easy for me to understand because it } \\
\text { was close to classical mechanics. }\end{array}$ & 47 & 190 & 227 & 178 & 47 & 2 & 2,98 Mod. \\
\hline 14 & $\begin{array}{l}\text { The way the topic was explained made it } \\
\text { easy for me to understand. }\end{array}$ & 76 & 253 & 181 & 126 & 49 & 6 & 2,74 Mod. \\
\hline 16 & It is easy to understand the topic. & 64 & 178 & 202 & 169 & 67 & 11 & 3,00 Mod. \\
\hline \multirow[t]{2}{*}{21} & $\begin{array}{l}\text { It was easy for me because I understood the } \\
\text { logic of relativity. }\end{array}$ & 66 & 244 & 190 & 151 & 37 & 3 & 2,78 Mod. \\
\hline & Averages & 78,5 & 227,7 & 189,5 & 143,7 & 46,7 & 5,0 & 2,79 Mod. \\
\hline
\end{tabular}


In Table 4, when the general average of the second factor consisting of the items about the way the topics are explained is regarded, it can be said that there was difficulty at "Moderate" level except one item. However, it can be said that easy answers conglomerate towards "2" ("Easy") in all of the items except two of them. According to it, it can be thought that the students are inclined to characterize the topic as "Easy" after they understand once the logic and philosophy of relativity generally. It was determined that the difficulty level was often high in the items seen about the teaching technique (Item 7).

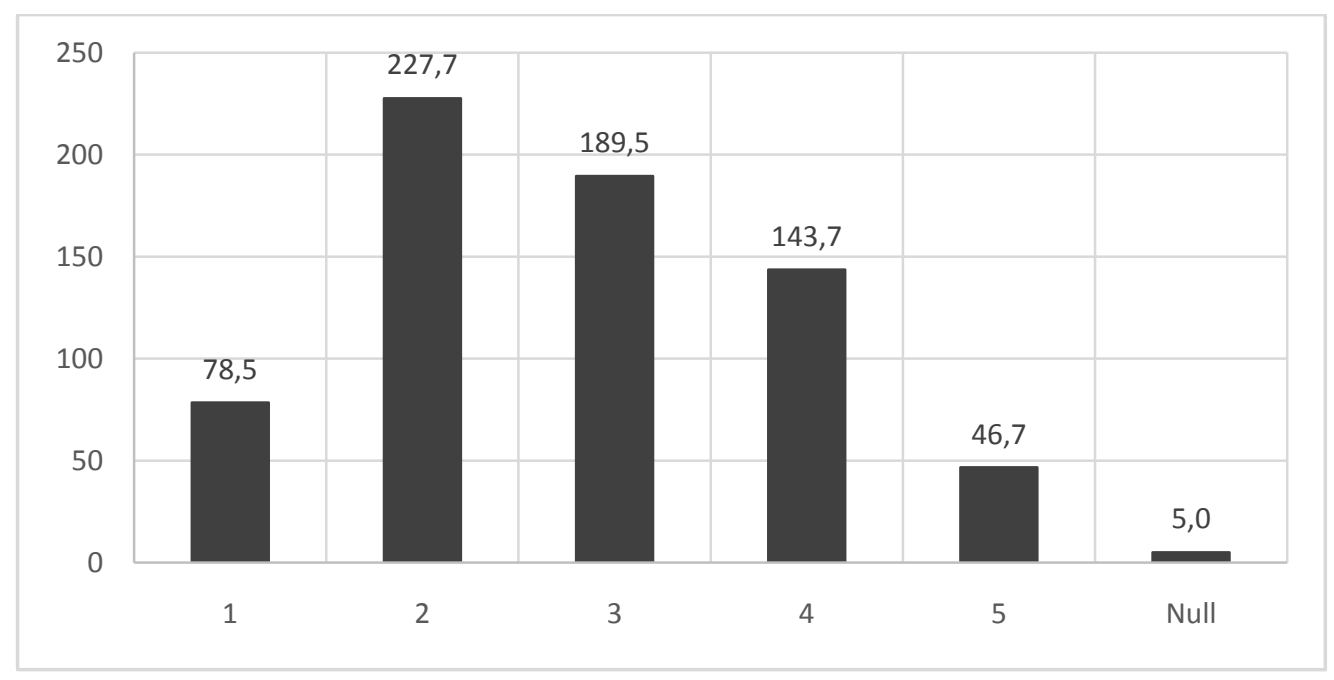

Figure 3.

Dispersion of the average difficulty level for the second factor

As it is seen in Figure 3, the general difficulty levels of the students about the second factor are inclined to " 2 ". In other words, even if it indicates that there is difficulty at a moderate level in the average, it can be said that there is an inclination to "Easy" in this factor.

Table 5.

Frequency dispersion of the answers given to the items in the third factor

\begin{tabular}{|c|c|c|c|c|c|c|c|c|c|}
\hline \multirow{2}{*}{$\begin{array}{c}\text { Item } \\
\text { No }\end{array}$} & \multirow{2}{*}{ Item } & \multicolumn{2}{|c|}{ VeryEasy $\leftarrow$} & \multicolumn{4}{|c|}{$\begin{array}{r}\rightarrow \\
\text { VeryDiffucult }\end{array}$} & \multirow[b]{2}{*}{$\begin{array}{l}\text { Avr. } \\
\text { Score }\end{array}$} & \multirow[b]{2}{*}{ Range } \\
\hline & & 1 & 2 & 3 & 4 & 5 & Null & & \\
\hline 17 & $\begin{array}{l}\text { Its requiring mathematical knowledge / skills } \\
\text { made it difficult for me to understand. }\end{array}$ & 81 & 227 & 181 & 153 & 47 & 2 & 2,79 & Mod. \\
\hline 18 & It is difficult to solve the problems. & 52 & 205 & 163 & 209 & 57 & 5 & 3,02 & Mod. \\
\hline \multirow[t]{2}{*}{22} & I have difficulties in converting the units. & 72 & 170 & 161 & 205 & 78 & 5 & 3,07 & Mod. \\
\hline & Averages & 568,3 & 200,7 & 168,3 & 189,0 & 60,7 & 4,0 & 2,96 & Mod. \\
\hline
\end{tabular}

In Table 5, when the general average of the third factor consisting of the items about the students' mathematical difficulties is regarded, it can be said that there is difficulty at "moderate" level. However, it is seen that the answers given to the 22 nd item conglomerate towards " 4 " and they conglomerate towards " 2 " in the 17th item. The mentioned mathematical skills' being different skills can be the reasons for it. Conglomeration towards both to " 2 " and " 4 " in the 18th item indicate that there is a balanced dispersion in the students' perception of problems as easy and difficult. 
Kızılcık ve Yavaş - Çukurova Üniversitesi Eğitim Fakültesi Dergisi, 46(2), 2017, 399-426

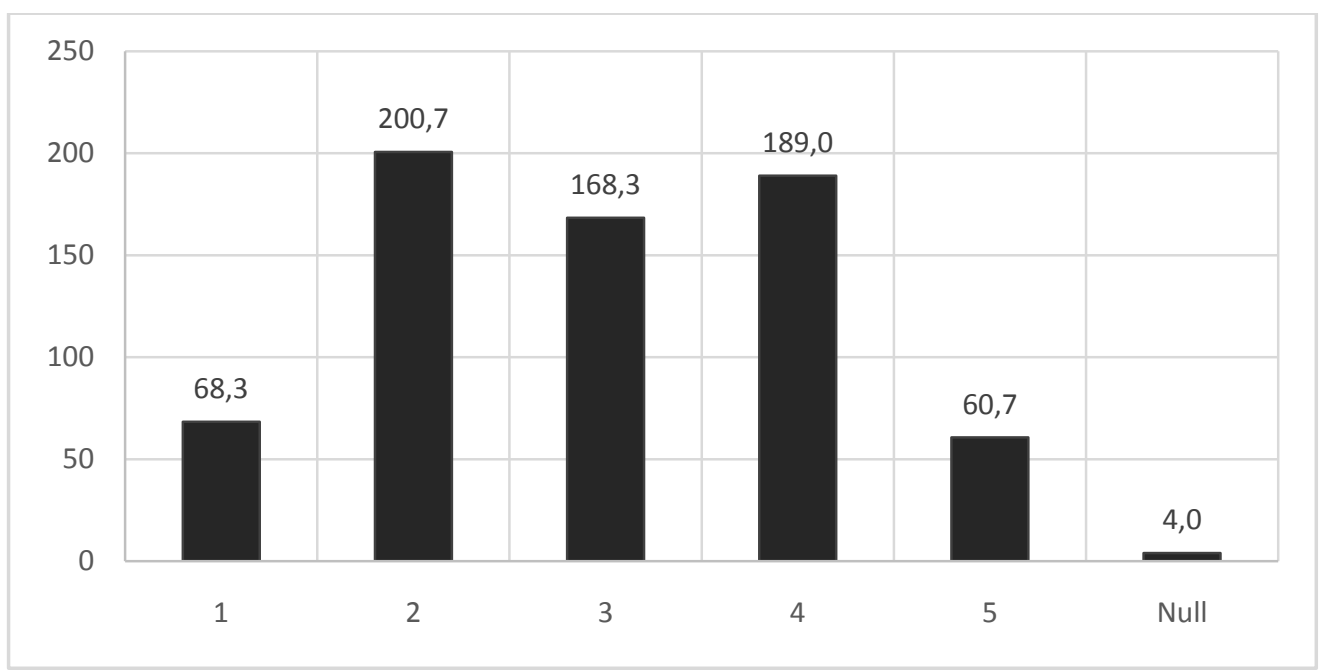

Figure 4.

Dispersion of the average difficulty level for the third factor

As it is seen in Figure 4, a balance is in question in the students' difficulty levels about the third factor. However, it is seen that the inclination is a little more dominant towards " 2 ". In other words, even it indicates that there is difficulty at a moderatelevel, it can be said that there is an inclination towards "Easy" in this factor.

It is seen that the participation is high in the difficulty of interpreting relativity in the 4th item in the first factor. In the 21st item in the second factor, the students agree with the opinion which states that relativity is not difficult when its logic is understood. If these two items are approached together, it can be concluded that it is a topic which is understood hardly by the students but they think that it is a topic which they see as not difficult when it is understood. We can aslo connect the high participation in having prejudices about the topic's being difficult mentioned in the 15th item to this result.

On the basis of frequency, it was seen that the difficulty level increased in the items directly or indirectly about the mathematical difficulties in the first and third factors (Items 1, 19, 22). However, intensity is seen in the item indicating that the students did not have difficulties in terms of mathematics (Item 17). Similarly, conglomeration at high level was seen in the items about extra effort, time and endeavor (Items 3, 8) and the item about the prejudices about the difficulty of the topics (Item 15) in the first and second factors at high difficulty level.

\section{Comparison of the Data AccordingtoEducational Level andGender}

Whether the students' answers differed depending on gender or educational level or not was analysed. For this purpose, the averages of the answers of the male and female students and high school and university students were approached seperately. 


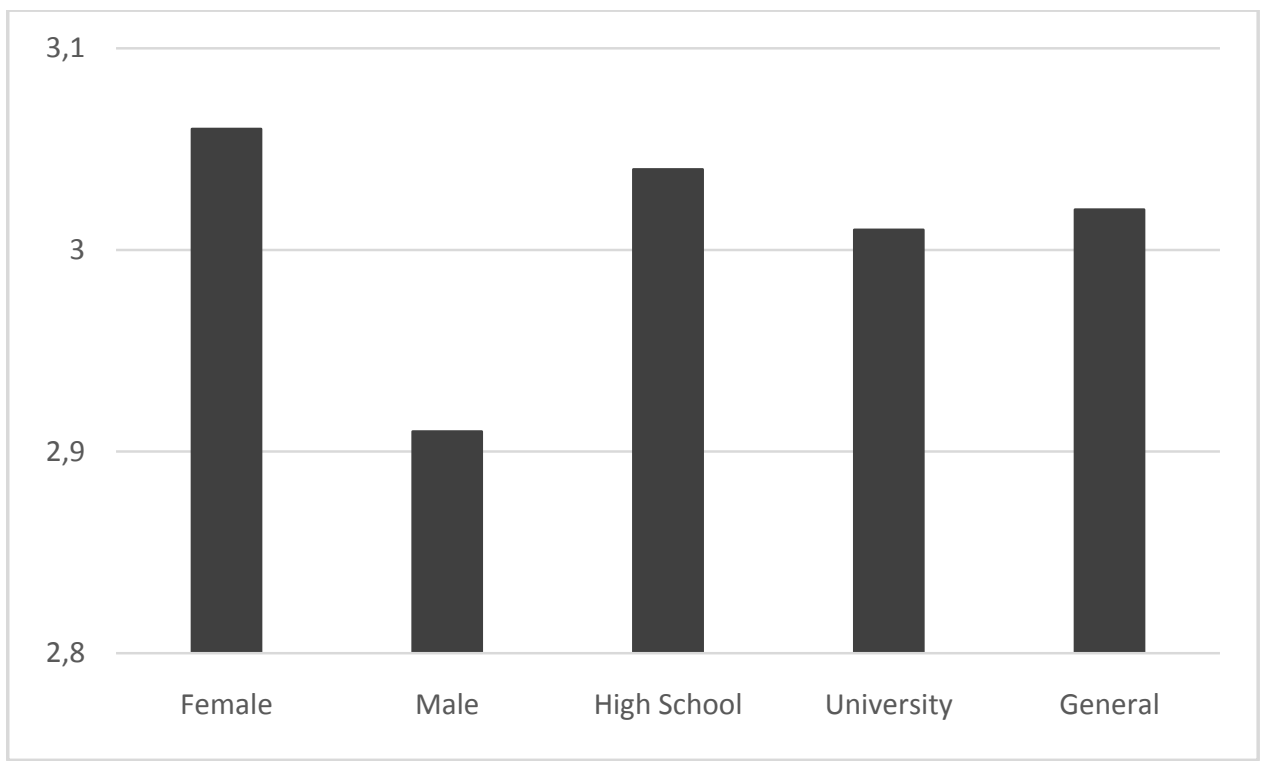

Figure 5.

Average scores of the groups

As it is seen in Figure 5, there are small differences between the averages of the answers given by the groups to the scale. Because of this reason, it will be useful to make a more detailed comparison of the answers according to factors and the items in the factors. Dispersion of the averages of the answers of the male and female students and the high school and university students according to the factors is given in Table 6.

Table 6.

Average Scores According to Sex and Educational Level

\begin{tabular}{lllllllllll}
\hline \multirow{2}{*}{ Factors } & \multicolumn{2}{c}{ Female } & \multicolumn{2}{c}{ Male } & \multicolumn{2}{c}{ High School } & \multicolumn{2}{c}{ University } & \multicolumn{2}{c}{ General } \\
\cline { 2 - 11 } & Avr. & Level & Avr. & Level & Avr. & Level & Avr. & Level & Avr. & Level \\
\hline First Factor & 3,19 & Mod. & 3,00 & Mod. & 3,12 & Mod. & 3,13 & Mod. & 3,13 & Mod. \\
\hline Second Factor & 2,80 & Mod. & 2,72 & Mod. & 2,86 & Mod. & 2,47 & Easy & 2,79 & Mod. \\
\hline Third Factor & 3,00 & Mod. & 2,87 & Mod. & 2,98 & Mod. & 2,95 & Mod. & 2,96 & Mod. \\
\hline General & 3,06 & Mod. & 2,91 & Mod. & 3,04 & Mod. & 3,01 & Mod. & 3,02 & Mod. \\
\hline
\end{tabular}

When the Table 6 is analysed, it is seen that all difficulty levels in terms of gender and educational level are in the "moderate" level range except one. The university students' average was found in the "easy" range only in the second factor. It indicates that university students have less difficulties than the high school students about the teaching methods of the topic.

When all of the scale items were analysed, if there was a meaningful difference between the answers of the high school and university students was determined with t test. According to the results of the $t$ test made, a significant difference was seen in high school students in Item 2 in the first factor and the Item 7 and Item 14 in the second factor and in the university students in Item 13 in terms of difficulty reasons. The $t$ value of the mentioned items whose significance value is below 0,05 and their significance value according to it are as follows: 2 nd item $(2,126 ; p: 0,034)$, 7 th item $(2,496 ; p: 0,013)$, 13th item (-2,320; p: 0,021), 14th item (2,044; p: 0,042). In other words, university students have difficulties at a lower level about the teaching methods. On the contrary, it is understood that university 409 
students characterize the topics as abstract topics more than the high school students in a significant way.

Results of the $t$ test according to gender indicate that women have more difficulties than men at a significant level in some items. They are the Items 1, 4, 6, 8, 11, 13, 23 in the first factor, Item 16 in the second factor and Item 22 in the third factor. The $t$ value of the mentioned items whose significance value is below 0,05 and their significance value is as follows: 1 st item (t: 2,275; $\mathrm{p}: 0,023), 4$ th item (t: 2,855; p: 0,005), 6th item (t: 2,936; p: 0,004), 18th (t: 2,064; p: 0,040), 11th item (t: 2,919; $p: 0,004)$, 13th item (t: 2,988; p: 0,003), 16th item (t: 2,110; p: 0,036), 22nd item (t: 2,296; p: 0,022), 23rd item (t: 4,$978 ; \mathrm{p}: 0,000$ ). According to this, it was determined that women had more difficulties in the items about the mathematical difficulties and the perceptive difficulties because of the classical physics modern physics paradigm change.

\section{Conclusion \& Discussion}

The findings obtained from the answers given by the high school and university students who have learned special relativity in their classes to the difficulty reasons scale indicate that the students think that this topic is easy as much as it is difficult. When the specific part of the topic is analysed, characterization of the expressions in each item as difficult or easy by the students can depend on gender or educational level but it can also change independently other than them.

When the findings of the high school students and university students are compared, no distinct difference is seen in terms of scale scores. However, when the difficulties for each other were compared seperately for high school and university students, it was seen that high school students had more difficulties in terms of its requiring more efforts and time in terms of explanation of the subject. We think that it was because different teaching methods were not used during teaching in respect to the topic's being more narrow-scoped. In order to explain this subject, teaching methods used in teaching relativity can be searched with an additional exercise. Because if special relativity is taught only in a mathematical way, students cannot understand what the difference between special relativity and classical relative concepts is (Arriassecq and Greca, 2012). In the body of literature, it is remarked that students have various conceptual difficulties in learning the theory of relativity (Dimitriadi and Halkia, 2012; Villani and Pacca, 1987; Korkmaz et al, 2016; Sherr et al, 2001; Sherr, 2007). In the recommendations for overcoming these difficulties in the body of literature, usually the variety of teaching methods are emphasized. For example, thought experiments and use of paradoxes (Cornier and Steinberg, 2010; Cacioppo and Gangopadhyaya, 2012; Velentzas and Halkia, 2013), computer simulations and games (Kraus, 2008; Wegener et al, 2012; Savage et al, 2007; Carr and Bossomaier, 2011) and use of some experiments (Singh and Hedgeland, 2015) are recommended for teaching special relativity.

Findings about the factor of perception about the topic indicate that the students agree with the expression of difficulty about understanding the differences between classical physics and relativity. Moreover, from the findings, it is understood that there is a conglomeration in the high difficulty level of the answers given to the related items about the difficulties caused by the paradigm change about the transition from classical physics to modersn physics. It attracts attention that especially female students have more difficulties than male students in this topic. According to the body of literature, the students are inclined to use classical physics while answering the questions about relativity (Turgut et al, 2013; Pietrocola and Zylberztajn, 1999). Even if the students solve the problems about special relativity, they have difficulties in changing the classical ways of thinking in the process of comprehending the main concepts of relativity (Arriassecq and Greca, 2012). Sherr (2007) remarks that the experiences we have in daily life cause this difficulty. Moreover, the findings of this study indicate that the students' rates of agreeing with the idea of their having deficiencies in classical physics is high. Similar results are also seen 
in the study conducted by Selçuk (2011). Sherr et al (2001) indicated that the reason underlying the failures of the students in special relativity were the deficiencies in their understanding the basic topics.

One of the students' reasons of difficulties in special relativity is the mathematical difficulty. In the items about mathematical difficulties making the third factor, it is understood that the students had mathematical difficulties. However, the number of the people who think that the mathematics of the topic is not difficult is quite high, even most of the students did not agree with the idea of having difficulties in terms of mathematical skills in the 17th item. When the finding of the significant difference between the high school and university students is added to this situation, it can be commented that the scope and the mathemaical content of the topic taught at high school and university being different caused it. In addition, a significant difference was found in the expressions containing mathematical difficulties. Women remarked that they had more difficulties in the items containing mathematical skills. Studies should be made to research the reasons of it. In the body of literature, attention is drawn to the difficulties of the students about the theory of relativity (DidişKörhasan and Özcan, 2015; Turgut et al, 2013; Ogborn, 2005). Angell et al (2004) remark that the students did not regard mathematics as a problem but the teachers complained about the deficiencies in the mathematical skills of the students, in the results of their study in which they searched the students' and tearchers' opinions about physics lessons. Again, the results of this research indicate that the students found the topic of relativity interesting. We think that reducing the mathematical content and arranging the main concepts of the topic in a way the students can understand will be more effective in teaching the theory of relativity. In relation to that, Velentzas and Halkia (2013) drew attention to the advantages of using thought experiments in teaching special relativity in terms of its being in story style and containing less mathematics. Arriassecq and Greca (2007) remarked that preparing suitable and motivating materials in teaching special relativity would be effective in enabling the students to learn meaningfully. 


\section{Türkçe Sürümü}

\section{Giriş}

Einstein'ın Görelilik Teorisi fiziksel dünyaya dair düşüncelerimizi kökten değiştirmiştir. 20. yüzyıla gelinceye kadar sahip olduğumuz mutlak zaman ve uzay kavramları değişerek yerini yeni uzay-zaman kavramı almıştır. Bu değişimle birlikte görelilik teorisinin öğretimi de zorunlu hale gelmiştir. Görelilik teorisi öğrenilmesi ve öğretilmesi zor olan kavramlar ve olgulardan oluşmaktadır. Örneğin, Penrose (1959), Terrell (1959) ve Weisskopf (1960) göreli olarak hareket eden bir nesnenin fotoğrafının Lorentz kısalmasının öngördüğünden farklı olduğunu belirtmiştir. Diessler (2005) özel göreliliğin öğretiminde zaman genişlemesi ve boy kısalmasını açıklarken 'ölçüm' ve 'gözlemci' gibi sözcüklere vurgu yapmanın önemini belirterek boy kısalması için 'görmek' gibi sözcüklerin kullanılmamasını önermiştir. Bunun sebebi cismin farklı kısımlarının gözlemciye farklı uzaklıklarda olmasından kaynaklanan optik etkilerdir. Einstein'ın özel görelilik kuramını bu kadar derin yapan şey, uzunluğun gerçekten kısaldığı ve zamanın gerçekten yavaşladığı gerçeğidir. Bu sadece görünüş meselesi değildir. Lorentz kısalmasının göreli hareket eden bir cismin fotoğrafik görüntüsünden farklı olduğunu göstermek için Terrell etkisi olarak bilinen bu durumun gösterilmesi için sınıfta yapılacak alıştırmaların sunulduğu çalışmalar vardır (BurkevaStrode, 1991).

Görelilik teorisini anlama güçlüklerinin çoğu, göreli etkilerin günlük tecrübelerin bir parçası olamamasından ve günlük tecrübelerle çelişiyor gibi görünmesinden kaynaklanmaktadır. Ayrıca, göreli etkileri gösteri deneyleri yoluyla doğrudan gözlemlemek mümkün değildir (Kraus, 2008). Özel görelilik görünüşte tuhaf etkilere sahiptir ve ağırlıklı olarak günlük deneyimin dışındaki durumlarla ilgilidir. Görelilik teorisinin öğretiminde düşünce deneylerinin kullanılması öğrencilerin günlük yaşantılarının ötesindeki durumları fark etmelerini sağlamaktadır. Bu da göreliliğin ilke ve yasalarını kavramalarını kolaylaştıracaktır (Velentzas ve Halkia, 2013). Bununla ilgili olarak, Al-Khalili (2003) göreliliğin öğretiminde birçoklarının aksine zaman yolculuğu fikrini kullanmanın, hayal gücünü ortaya çıkarma ve uzay-zamanın doğasını anlamada bir fırsat sunacağını iddia etmektedir. Özel göreliliğin ilginç özelliklerini vurgulamada kullanılabilecek güzel örnekler olduğunu ifade etmektedir. Özel göreliliğin öğretiminde paradoksların önemine dikkat çeken Cacioppo ve Gangopadhyaya (2012) üniversite öğrencilerine yönelik uzunluk kısalması hakkında iki düşünce deneyi sunarak bunların öğrencilere konu hakkında daha derin bir anlama sağlayacağını belirtmiştir. Göreli etkilerin sanal olarak deneyimlendiği simülasyonlar ve bilgisayar oyunları, göreliliğin öğretiminde günlük tecrübelerle ilgili eksikliklerle başa çıkmada kullanılmaktadır. Wegener, McIntyre, McGrath, Savage ve Williamson (2012), özel göreli fiziğe uyan bir dünyayı simüle eden oyun benzeri sanal gerçekliğin kullanıldığı bir öğretim paketini başarılı bir şekilde kullanmışlardır. Kortemeyer, Fish, Hacker, Kienle, Kobylarek, Sigler, Wierenga, Cheu, Kim, Sherin, Sidhu ve Tan (2013) öğrencilerin özel göreliliğin öğretiminde kullanılacak bir bilgisayar oyunu geliştirmişlerdir. Savage, Searle ve McCalman (2007) göreli hızlarda hareketin olduğu, simüle edilmiş bir dünyada hareket imkanı sağlayan bilgisayar programıyla, uzunluk kısalması ve aynıandalığın göreliliğini öğrencilerin keşfedeceklerini söylemektedir. Carr ve Bossomaier (2011) bilgisayar oyununa özel görelilik etkilerini yerleştirerek yaptıkları uygulamada öğrencilerin konuyu kavrayışlarında ve motivasyonlarında iyileşme gerçekleştiğini belirtmiştir. Sherin, Cheu, Tan ve Kortemeyer (2016) özel göreliliğin etkilerinin deneyimlenebileceği bilgisayar oyunu sayesinde özel göreliliğin soyut kavram ve konularının ilk elden deneyimler sağlayacağını belirtmiştir. Geliştirdikleri oyunun internet ortamında ilgi gördüğünü ve olumlu geri dönütler olduğunu rapor etmişler. Belloni, Christian ve Dancy (2004) özel göreliliğin soyut kavramlarını görselleştirmede yararlı olacak Physlet tabanlı alıştırmaları tanıtmıştır.

Göreliliğin öğretiminde bir diğer zorluk klasik fizik-göreli fizik paradigma değişiminin öğrenciler tarafından algılanamamasıdır. Arriassecq ve Greca (2012)'a göre öğrenciler klasik fizik ile özel göreliliğin içerdiği kavramlar arasındaki farkı anlayamamaktadır. Gim (2016) Güney Kore'de lisede öğretilen özel 
görelilik teorisinin ders kitaplarında nasıl yer aldığını araştırdığı çalışmasında, teorinin fizik teorileri açısından devrimsel yönüne vurgu yapmadığını belirtmektedir. Ireson (1996) makalesinde, özel göreliliğin öğretiminde geleneksel olan yolun, Michelson-Morley deneyinin ışık hızı ile ilgili sonuçlarından bahsetmek, referans çerçevelerine olan ihtiyacı ortaya koymak ve özel göreliliğin iki ilkesini tanımlamak olduğunu belirtmiştir. Bunun yerine Newtoncu ve Aristocu dünya görüşünden başlayarak, öğrencileri bunun eksiklerini fark edebilecekleri durumla karşı karşıya bırakıp, soruna çözüm bulmalarında yardımcı olma yoluyla özel göreliliğin öğretilmesini önermektedir. Dimitriadi ve Halkia (2012) lise öğrencilerinin özel görelilik teorisini öğrenme süreçlerine yönelik araştırmasının sonuçlarına göre, öğrenciler klasik mekanikte öğrendikleri mutlak hareket fikrini derinleştirdikleri, bunun da göreliliğin öğretilmesinde öğrencilerin klasik fiziğe göreliliği dahil etmeye çalışmalarına sebep olduğunu söylemektedirler. Pietrocola ve Zylberztajn (1999)'in çalışması, öğrencilerin özel görelilik ile ilgili problemlerde klasik mekanik ve sağduyu dışındaki yorumlayııı yapıları kullanma ihtiyacı hissetmediklerini göstermiştir. Arriassecq ve Greca (2012)'ya göre klasik fizik ile göreli fizik arasındaki değişimin öğrencilere kavratılmasında tarihsel ve epistemolojik bağlamın kullanılmasının olumlu etkileri söz konusudur. Ek olarak, Seçkin Kapucu (2016) görelilik teorisini içeren bir belgesel üzerinde yaptığı nitel çalışmada, belgeselin bazı bilimin doğası temalarının ve kavramların öğretiminde kullanılabileceğini belirtmiştir. Ayrıca bu tür belgesellerin öğretimde kullanılmasının öğrencilerin öğrenmeye yönelik motivasyonlarını arttıracağını söylemiştir. Villani ve Arruda (1998) özel göreliliğin öğretiminde Lorentz dönüşüm denklemleri ve Einstein'ın denklemleri ile yorumlanabilecek deneysel sonuçlar ve uygulamalara daha fazla odaklanılması gerektiğini ve klasik fikirler ile modern olanlar arasındaki farkların vurgulanmasının önemli olduğunu söylemektedirler. Bunun için bilim tarihindeki kavramsal değişimin varlı̆ııın ve temel özelliklerinin farkına varabilecekleri bir öğretim ortamının gerekliliğini ifade etmektedir.

Göreliliğin öğrenilmesinin zor olmasının sebeplerinden biri de öğrencilerin klasik fizikteki eksikleridir. Scherr, Shaffer ve Vokos (2001) özel görelilikte zaman kavramı ve referans çerçevelerinin rolü hakkında öğrencilerin kavramsal ve mantıksal zorluklarıı araştırmıştır. Sonuçlar, tüm akademik kademelerde öğrencilerin eşzamanlılı̆ın göreliliği ve eylemsiz referans sistemlerinde gözlemcinin rolü konularında ciddi zorluklar yaşadığını göstermektedir. Öğrencilerin mutlak eşzamanlılık ile eşzamanlıığın göreliliğinin bir arada bulunduğu kavramsal bir çerçeve oluşturmaktadır. Illeri seviyedeki öğrencilerin bile fiziksel dünyayı anlamada özel göreliliğin etkilerini yorumlamakta başarısız olduğu görülmüştür. Öğrencilerin bu başarısızıklarının altında yatan sebep daha temel konuları anlamalarındaki eksiklikler olduğunu belirtmektedirler.

Görelilik teorisi öğrenilmesinin zor olması yanında ilgi çekici ve merak uyandırıcı bir konudur. Angell, Guttersrud, Henriksen, ve Isnes (2004) Norveç'te hem öğretmenler hem de öğrencilerin fizik ve fizik öğretimine yönelik düşüncelerini araştırmıştır. Bu çalışmaya göre, görelilik diğer fizik konuları içerisinde ilginç olması bakımından ikinci sıradadır. Ogborn (2005)'e göre öğrenciler göreliliği öğrenmeye başladıklarında oldukça hevesliyken Lorentz dönüşümleri ve bazı karmaşık cebirsel işlemlerle karşılaştıklarında bu heveslerini kaybetmektedirler. Angell (2004) çalışmasının sonuçlarına göre öğretmenler öğrencilerin zayıf matematik becerilerinden yakınmakta, öğrenciler ise fizik derslerinde matematiği önemli bir sorun olarak görmemektedirler.

Arriassecq ve Greca (2007) Arjantin'de lise ve üniversite ders kitaplarını içerik yönünden incelemiş ve lisede öğretilmeye başlanan özel görelilik teorisinin öğretmenlere yönelik ders materyallerinin bağlamsal perspektif yönünden yetersizliğine dikkat çekmiştir. Özel göreliliğin öğretiminde kavramsal olarak uygun ve motive edici materyallerin hazırlanmasının öğrencilerin anlamlı öğrenmesini sağlamada etkili olacağını belirtmiştir. Smith (2011) öğrencilerin özel görelilik kavramlarını daha iyi anlayabilmesi için görselleştirmenin yararlarına vurgu yaparak, elektromanyetik alan içinde göreli hızlarla hareket eden bir elektrik dipolünü görselleştirmek üzere kullanılan grafiklerin ve basit hesapların, ışığın eylemsiz referans çerçevelerinde sabitliği, Doppler etkisi gibi olguları açıkça gösterdiğini belirtmiştir. Ogborn'a göre (2005) öğrenciler göreliliği öğrenmeye başladıklarında oldukça hevesliyken Lorentz dönüşümleri ve bazı karmaşık cebirsel işlemlerle karşılaştıklarında bu heveslerini kaybetmektedir. Yazar, özel göreliliğin öğretiminde öğretmenlerin yararlanabileceği dört adımdan oluşan ve öğretmenin seçimine bağlı olarak 413 
istedikleri aşamada durabilecekleri bir öğretim materyali önermiştir ve daha az şey öğretmenin rölativistikdüşüncenin özünü kavratmak açısından daha fazlasını başarabileceği konusunda uyarıda bulunmuştur. Scherr, Shaffer ve Vokos (2002) öğrencilerin özel görelilik kavramlarını, aynıandalığın göreliliğini ve eylemsiz referans çerçevelerinde gözlemcinin rolünü anlamalarını geliştiren bir öğretim materyali oluşturmuştur ve bu materyalin öğrencilerin özel görelilikteki klasik paradoksların bazılarını tanıma ve çözme becerilerini önemli ölçüde geliştirdiğini belirtmektedirler. Guisasola, Solbes, Barragues, Morentin ve Moreno (2009) özel görelilik teorisinin birinci yüzyılı dolayısıyla hazırlanan sergi ziyaretinin öğrencilerin özel görelilik teorisi hakkındaki bilgi, ilgi ve anlayışlarını arttırdığını rapor etmiştir. Öğrencilerin ışığın hızı, zaman ve referans sistemi, kütle ve enerji konularında ziyaret öncesi ve sonrası bilgi düzeylerinde artış belirlenmiştir.

Son zamanlarda ülkemizde bu teorinin öğretimine verilen önem artmış lise fizik öğretim programlarında yer almaya başlamıştır. Özel görelik teorisi 2007 fizik öğretim programında (MEB, 2007) onuncu sınıfta, güncellenen 2013 fizik öğretim programında (MEB, 2013) matematiği azaltılmış olarak on ikinci sınıfta bulunmaktadır. Teori üniversitelerin fizik ve fizik öğretmenliği bölümlerinden başka fen bilgisi öğretmenliği bölümlerinde de okutulmaktadır. Ülkemizde göreliliğin öğretimine olan ilginin artmasına paralel olarak bu konu hakkında fen eğitimi araştırmaları da son yıllarda artış göstermiştir (Demir ve Akarsu, 2014; Didiş Körhasan ve Özcan, 2015; Selçuk, 2011; Özcan, 2011; Ünlü Yavaş ve Kızılcık, 2016; Yıldız, 2012).

Ülkemizde özel görelilik teorisi ile ilgili, genellikle üniversite öğrencileri ile araştırmalar yapılmıştır. Selçuk (2011) üniversite öğrencilerinin özel görelilik teorisinin içinde yer alan has zaman, zaman genişlemesi, has boy, kütle ve yoğunluk kavramlarında güçlüklerini belirlemiştir. Özcan (2011) fizik öğretmen adaylarının özel görelilik kuramı ile ilgili problem çözme yaklaşımlarını incelemiş ve katılımcıların problem çözme yaklaşımlarının bilimsel ve stratejik olmadığı sonucuna varmıştır. Turgut, Gurbuz, Salar ve Toman (2013) fizik öğretmen adaylarının özel görelilik teorisini anlamaları hakkında yaptıkları nitel araştırmanın sonuçları, öğretmen adaylarının özel göreliliğin kavramlarını anlama ve yorumlamada sorunları olduğunu ortaya koymaktadır. Ayrıca bu konularla ilgili matematiksel zorluklar da görülmektedir. Didiş Körhasan ve Özcan (2015) üniversite öğrencilerinin özel görelilik ile ilgili problem çözümlerinde matematiksel model kullanmada zorlukları olduğunu belirtmiştir. Öğretmen adaylarının zorlanma sebepleri ile ilgili fikirlerinin araştırıldığı nitel çalışmada matematiksel güçlükler ve klasik fizikten göreli fiziğe geçiş ile ilgili güçlüklerin öne çıktığı rapor edilmiştir (Ünlü Yavaş ve Kızılcık, 2016). Demir ve Akarsu (2014)'nun hem lise hem de üniversite öğrencileri ile yaptığı çalışma, özel göreliliğin modern fizik konuları içerisinde öğrencilerin zorlandıkları konulardan biri olduğunu göstermektedir. Lise öğrencileriyle yapılmış bir diğer araştırmada özel görelilikle ilgili kavram yanılgıları araştırılmıştır (Korkmaz, Aybek ve Örücü, 2016). Yıldız (2012) öğrenme amaçlı yazma etkinliklerinin, öğretmen adaylarının özel görelilik teorisini anlamalarına katkısı olduğunu belirtmektedir.

Görelilik ile ilgili öğrenci güçlüklerinin araştırıldığı çalışmalarda, genellikle öğrencilerin görelilik ile ilgili sorulara verdikleri cevaplara dayanarak zorluklar belirlenmiştir. Literatürde, öğrencilerin fizikte zorlanmalarının sebeplerinin araştırıldığı birçok çalışma olmasına karşın, görelilik ile ilgili öğrencilerin zorlanma nedenlerinin yine öğrencilere sorulduğu bir çalışmaya rastlanmamıştır. Bu nedenle bu araştırma, görelilik konularında öğrenci güçlüklerinin sebeplerini belirleme açısından diğer araştırmalardan farklıdır. Bu araştırmada, öğrencilerin nitel olarak önceden verdikleri güçlük nedenleri ile ilgili yanıtlardan yararlanarak oluşturulan nicel bir ölçekten yararlanılmıştır. Araştırmanın amacı lise ve üniversite öğrencilerinin özel görelilik konusunda zorlanma nedenlerinin görülme sıklığını belirlemektir. Ayrıca, eğitim düzeyi ve cinsiyete göre bu nedenlerin sıklığında farklılık olup olmadığının da incelenmesidir.

\section{Yöntem}

Araştırma tarama çalışması olarak tasarlanmıştır. Araştırmaya, önceden yazarlarca yapılannitel bir çalışmanın (Ünlü Yavaş ve Kızılcık, 2016) verilerinden yararlanarak başlanmıştır. 


\section{Veri Toplama Aracı}

Önceki çalışma özel görelilik konularının öğretiminden sonra 25 fizik öğretmen adayıyla yapılmıştı. Katılımcıların zamanda görelilik, uzunlukta görelilik, Lorentz dönüşüm denklemleri, Lorentz hız dönüşüm denklemleri, göreli momentum ve göreli enerji konularının zorluk veya kolaylığı hakkındaki görüşleri yapılan görüşmelerle belirlenmişti. Görüşmeler sırasında zorlanma nedenlerinin; öğrencilerin öğretim yöntemi, matematiksel sorunlar, klasik fizikten göreliliğe geçişte yaşanan sorunlar başta olmak üzere çeşitli nedenlere dayandığı görülmüştü. Bu görüşmelerin nitel analizinden elde edilen 28 görüşü düzenlendi ve uzman görüşü sonrasında Likert türü bir ölçeğin maddeleri haline getirildi. Böylece öğrencilerin maddelerde belirtilen zorluğa katılma derecelerini işaretleyebilecekleri 5 dereceli Likert bir ölçek elde edilmiş oldu. Ölçeğin puanlanması 5 ile 1 arasında katılma derecesini belirtecek biçimde hazırlanmıştır. Madde kolaylık bildiriyorsa bu puanlama ters çevrilerek yapılmıştır. Yani söz konusu her bir madde için belirtilen zorluğa katkı en yüksek 5 puan en düşük ise 1 puan olmuştur.

\section{Örneklem}

Söz konusu ölçek, özel görelilik konularını içeren ders almış olan 446 fen bilgisi öğretmen adayına ve 245 lise öğrencisine olmak üzere, toplam 691 kişiye uygulandı. Burada amaç, önceki çalışmada araştırmacılarca belirlenen zorlanma nedenlerinin öğrenciler arasında ne derecede yaygın olduğunu belirlemektir. Örnekleme ilişkin tanımlayıcı veriler Tablo 1'de verilmiştir.

\section{Tablo 1.}

Örneklemin tanımlayıcı özellikleri

\begin{tabular}{llc}
\hline Grup & Altgrup & Öğrenci Sayısı \\
\hline \multirow{2}{*}{ Öğretim } & Lise & 245 \\
\cline { 2 - 3 } Düzeyi & Üniversite & 446 \\
\hline \multirow{4}{*}{ Cinsiyet } & Kadın & 450 \\
\cline { 2 - 3 } & Erkek & 220 \\
\cline { 2 - 3 } & Bilinmiyor & 21 \\
\hline
\end{tabular}

Elde edilen verilerle açımlayıcı faktör analizi yapılmıştır. Buna göre, 28 maddelik ölçeğin ortak varyansları 0,399 ile 0,634 arasında değişmektedir. Özdeğeri 1'den büyük 4 faktör toplam varyansın \%50,637'sini açıklamaktadır. Ancak binişik maddeler (28 maddelik testte: 1, 8, 9, 20, 28. maddeler) silindiğinde ölçek 3 faktörlü yapı göstermiştir. Bu üç faktör toplam varyansın \%48,06'sını açıklamaktadır. Geriye kalan 23 maddeden oluşan test verilerine göre, birinci faktör 1, 2, 4, 5, 6, 8, 10, 11, 12, 13, 15, 19, 20, 23. maddelerden, ikinci faktör 3, 7, 9, 14, 16, 21. maddelerden, üçüncü faktör 17, 18, 22. maddelerden oluşmaktadır. Genel olarak, birinci faktörü oluşturan maddelere bakıldığında öğrencinin konuya yönelik algısını, ikinci faktör konuların anlatım biçimini ve üçüncü faktör matematik zorlukları içermektedir.

Verileri istatistik yazılımları aracılığı ile analiz edilmiştir. Elde ettiğimiz verilerin güvenilirlik katsayısını 0,91 olarak bulunmuştur. Maddeler arasında korelasyonun genelde yüksek olduğu saptanmıştır. Buna göre ölçeği iç geçerliliğinin yüksek olduğu söylenebilir.

Betimleyici analizler ve altgruplar arası karşılaştırmalar yapılmıştır. Likert maddelere, seçilebilecek en düşük zorluk düzeyinin 1, en yüksek zorluk düzeyinin ise 5 olması nedeniyle zorlanmaya etkisi derecelendirilmiştir. Verileri değerlendirirken uygulanan dereceler Tablo 2'de verilmiştir. 
Tablo 2.

Verilerindeğerlendirilmedereceleri

\begin{tabular}{cc}
\hline Ölçüt & Zorlanmaya etkisi \\
\hline $1.00-1.79$ & Çok kolay \\
\hline $1.80-2.59$ & Kolay \\
\hline $2.60-3.39$ & Orta \\
\hline $3.40-4.19$ & Zor \\
\hline $4.20-5.00$ & Çok zor \\
\hline
\end{tabular}

Likert türü maddelerin her birinin puanlarının Tablo 2'de belirttiğimiz aralıklardan hangisine düştüğüne bakılmıştır. Buna göre veriler bulgular bölümünde yorumlanmıştır. Ayrıca öğretim düzeyine göre ve cinsiyete göre anlamlı fark olup olmadığı bağımsız örneklem t-testinden yararlanarak incelendi.

\section{Bulgular}

Bu kısımda, verilerden elde edilen bulgular sunulmuş ve yorumlanmıştır. İlk olarak Likert türü ölçeğin betimleyici analizi yapılmıştır. Öğrencilerin yaptıkları seçimlerin 1-5 aralığında zorluk derecelendirmesine göre dağılımı ölçeğin tüm maddelerinin ortalamaları alınarak bulunmuştur ve Şekil 1'deki grafikte verilmiştir.

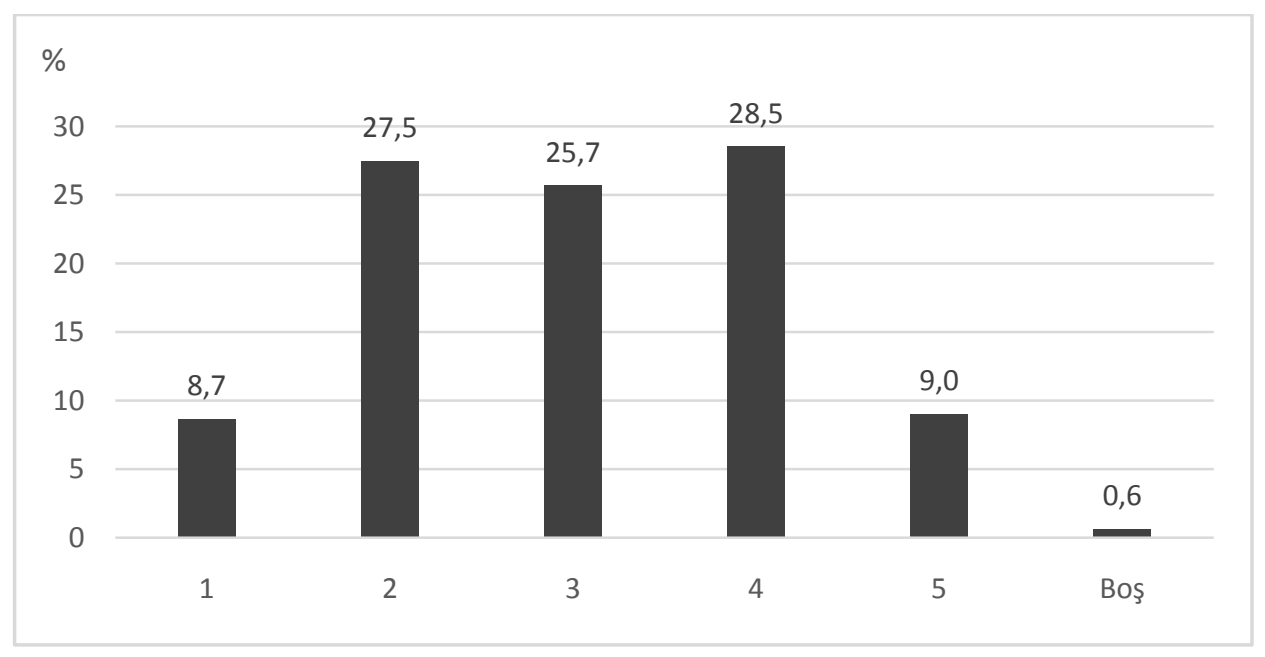

Şekil 1. Zorluk derecesinin yüzdelik dağılımı

Şekil 1'e göre, öğrencilerin daha çok 2, 3 ve 4. seçenekleri işaretlediği görülmektedir. Grafiğin zorluk derecelendirmesine göre ortadaki seçenek olan " 3 " baz alındığında simetriğe yakın bir dağılıma sahip olması öğrencilerin genel olarak görelilik konusunun zorlandıkları kadar kolay olduğunu da düşündüklerini göstermektedir. Hiçbir seçeneğin işaretlenme oranının \%30'u aşmadığı görülmektedir.

Tüm maddelerin ortalama puanları hesaplandığında, Tablo 2' de belirtilen ölçüte göre tümünün orta düzeyde güçlüğe sahip olduğu görülmüştür. Buna göre, öğrencilerin özel göreliliği genel olarak çok zor veya çok kolay olarak nitelendirilmediği söylenebilir. Madde puanlarının ortalamalarının orta düzeyde olması, öğrencilerin görelilikte zorlanma nedenleri açısından bize fazla bir bilgi vermez. Bu yüzden, her bir faktörü oluşturan maddeleri birlikte ele almak ve buna göre yorum yapmak yararlı olacaktır. 


\section{Faktörlere Göre Verilerin Incelenmesi}

Uygulanan 23 maddelik Likert türü ölçeğin verileri analiz edildiğinde üç faktörden oluştuğunu belirtmiştik. Bu faktörler ayrı ayrı incelenmiş ve tablolar halinde sunulmuştur. Şekil 1'de verilen zorluk derecesinin yüzdelik dağılımları grafiğinde belirlenen en yüksek değer \%28,5 idi. Bu nedenle tablolarda, toplam yanıtların \%28,5'i olan 197 yanıt ve üzerinde olanlar yatık ve kalın olarak işaretlenmiştir. Bu durum, yorum yapmayı kolaylaştıracaktır.

Birinci faktör olan konuya yönelik algının ağırlıklı olarak yer aldığı faktörün verileri, Tablo 3’te görülmektedir.

Tablo 3.

Birincifaktördeyeralanmaddelereverilenyanıtlarınfrekansdağılımı

\begin{tabular}{|c|c|c|c|c|c|c|c|c|c|}
\hline \multirow[b]{2}{*}{$\begin{array}{l}\text { Madde } \\
\text { No }\end{array}$} & \multirow[b]{2}{*}{ Madde } & \multicolumn{3}{|c|}{ Çok Kolay $\leftarrow$} & \multicolumn{3}{|c|}{$\rightarrow$ Çok Zor } & \multirow[b]{2}{*}{$\begin{array}{c}\text { Ort } \\
\text { Puan }\end{array}$} & \multirow[b]{2}{*}{ Aralık } \\
\hline & & 1 & 2 & 3 & 4 & 5 & Boş & & \\
\hline 1 & Bağıntıları anlayıp akılda tutmak zor. & 40 & 172 & 124 & 274 & 77 & 4 & 3,26 & Orta \\
\hline 2 & $\begin{array}{l}\text { Fazla çaba ve zaman harcamak gerektirdiği } \\
\text { için zor. }\end{array}$ & 49 & 186 & 159 & 228 & 67 & 2 & 3,11 & Orta \\
\hline 4 & Göreliliği yorumlamak zor. & 50 & 159 & 176 & 232 & 68 & 6 & 3,16 & Orta \\
\hline 5 & $\begin{array}{l}\text { Göreliliğe neden ihtiyaç duyulduğu anlamak } \\
\text { zor. }\end{array}$ & 80 & 178 & 188 & 179 & 64 & 2 & 2,96 & Orta \\
\hline 6 & $\begin{array}{l}\text { Günlük hayatta karşılaşılan bir durum } \\
\text { olmaması anlamamı zorlaştırdı. }\end{array}$ & 55 & 164 & 134 & 243 & 95 & - & 3,23 & Orta \\
\hline 8 & $\begin{array}{l}\text { Klasik fizikteki niceliklerden göreli niceliklere } \\
\text { geçiş aşaması zorlanmama neden oldu. }\end{array}$ & 39 & 164 & 195 & 226 & 67 & - & 3,17 & Orta \\
\hline 10 & $\begin{array}{l}\text { Klasik fizik konularında da genel eksikliklerim } \\
\text { olduğu için zorlandım. }\end{array}$ & 43 & 160 & 155 & 250 & 80 & 3 & 3,24 & Orta \\
\hline 11 & $\begin{array}{l}\text { Klasik ve göreli kavramları ilişkilendirmekte } \\
\text { zorlandım. }\end{array}$ & 43 & 167 & 182 & 232 & 61 & 6 & 3,15 & Orta \\
\hline 12 & $\begin{array}{l}\text { Klasik ve göreli kavramların ayrımını } \\
\text { yapmakta zorlandım. }\end{array}$ & 52 & 201 & 192 & 189 & 53 & 4 & 2,99 & Orta \\
\hline 13 & Konu soyut olduğu için zor geldi. & 60 & 165 & 157 & 224 & 79 & 6 & 3,14 & Orta \\
\hline 15 & Konunun zor olduğu hakkında önyargılıyım. & 60 & 158 & 182 & 200 & 82 & 9 & 3,13 & Orta \\
\hline 19 & $\begin{array}{l}\text { Referans sistemlerinin hangisinde hangi } \\
\text { niceliğin ölçüldüğünü belirlemek zor. }\end{array}$ & 27 & 154 & 236 & 202 & 68 & 4 & 3,19 & Orta \\
\hline 20 & $\begin{array}{l}\text { Sağduyuma/öngörülerime aykırı sonuçları } \\
\text { olması anlamamı zorlaştırdı. }\end{array}$ & 53 & 181 & 189 & 203 & 60 & 5 & 3,05 & Orta \\
\hline \multirow[t]{2}{*}{23} & $\begin{array}{l}\text { Yeni bir algı ve felsefe gerektirdiğinden } \\
\text { anlamak zor. }\end{array}$ & 51 & 191 & 173 & 225 & 50 & 1 & 3,05 & Orta \\
\hline & Ortalamala & $r 50,1$ & 171,4 & 174,4 & 221,9 & 69,4 & 4,3 & 3,13 & Orta \\
\hline
\end{tabular}

Tablo 3 incelendiğinde, öğrencilerin konuya yönelik algısına ilişkin maddelerden oluşan birinci faktörün genel ortalamasına bakıldığında, "Orta" düzeyde zorlanmanın olduğu söylenebilir. Ancak, maddelerin ikisi hariç tümünde beşli derecelendirmenin zorlanmayı belirten " 4 "e doğru yanıtların yığıldığı görülmektedir. Buradaki maddelerin büyük çoğunluğunun öğrencilerin klasik fizik ile görelilik arasındaki farkları algılamakta, yeni anlayışa uyum sağlamakta zorlanmaları ve günlük deneyimleri ve sağduyularına uydurmakta zorlanmaları ile ilişkili olduğu görülmektedir. Bunun yanı sıra, az da olsa matematik ile ilişkilendirilebilecek maddeler de olduğu belirlenmiştir. Klasik fizik-modern fizik paradigma değişiminin ortaya çıkardığı güçlükler ile ilgili maddelerde (Madde 4, 8, 11, 23); fazladan çaba, zaman ve 
emek harcama ile ilgili maddelerde (Madde 3, 8) ve konuların zor olduğuna ilişkin önyargı ile ilgili maddede (Madde 15) yüksek güçlük düzeyinde (Zor ve Çok zor) yığılma olduğu görülmüştür. Ayrıca klasik fizikten kaynaklanan sorunlar (Madde 10), konunun günlük yaşamla ilişkilendirilememesi ve soyut olarak görülmesi ile ilgili sorunlar (Madde 6, 13) da zorlanma nedeni olarak belirtilmiştir.

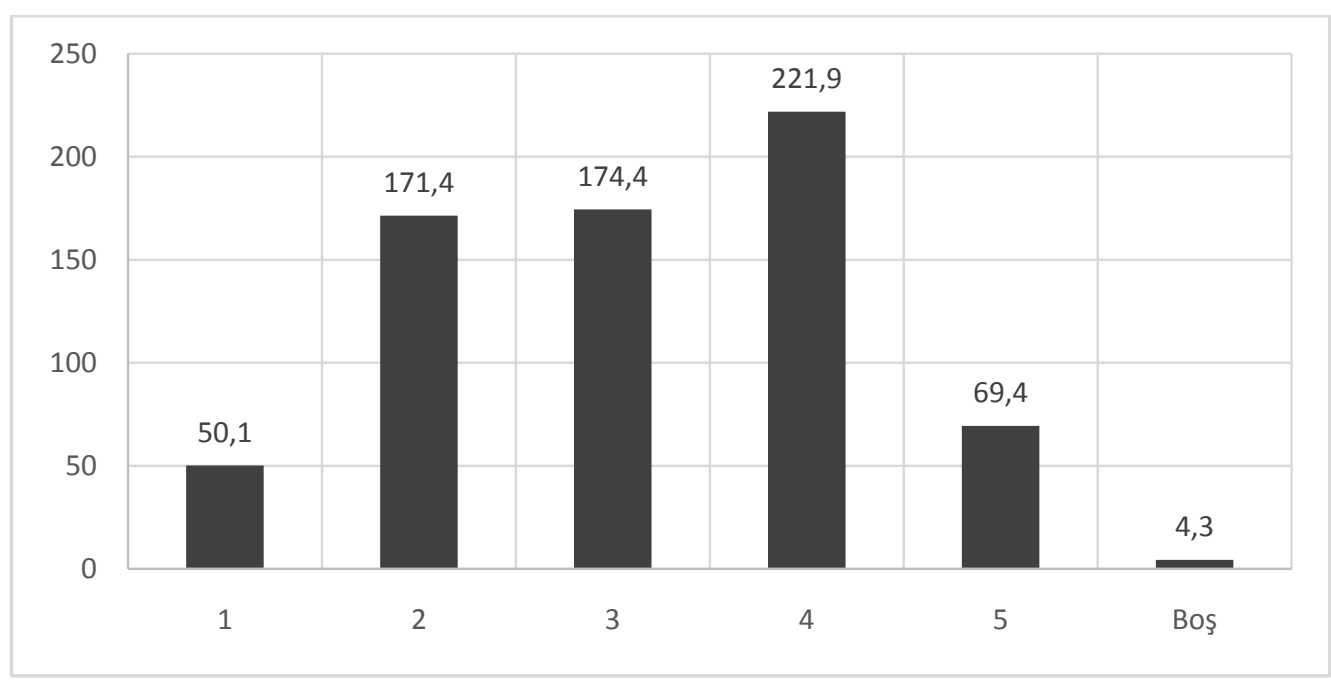

Şekil 2. Birinci faktör için ortalama zorluk derecesinin dağılımı

Şekil 2'de görüldüğü gibi, birinci faktöre ait öğrencilerin genel zorluk derecelerinin, beşli derecelendirmede "4"e eğilimli olduğu görülmektedir. Yani, her ne kadar ortalamalar "Orta" düzeyde bir zorluk olduğunu gösterse de, bu faktörde "Zor"a doğru bir eğilimin olduğunu söylenebilir.

Tablo 4.

ikincifaktördeyeralanmaddelereverilenyanıtlarınfrekansdağılımı

\begin{tabular}{|c|c|c|c|c|c|c|c|c|c|}
\hline \multirow{2}{*}{$\begin{array}{l}\text { Madde } \\
\text { No }\end{array}$} & \multirow{2}{*}{ Madde } & \multicolumn{3}{|c|}{ Çok Kolay $\leftarrow$} & \multicolumn{3}{|c|}{$\rightarrow$ Çok Zor } & \multirow[b]{2}{*}{$\begin{array}{c}\text { Ort } \\
\text { Puan }\end{array}$} & \multirow[b]{2}{*}{ Aralık } \\
\hline & & 1 & 2 & 3 & 4 & 5 & Boş & & \\
\hline 3 & $\begin{array}{l}\text { Göreli nicelikler, klasik niceliklerden daha } \\
\text { mantıklı olduğundan kolay. }\end{array}$ & 85 & 236 & 202 & 136 & 30 & 2 & 2,70 & Orta \\
\hline 7 & $\begin{array}{l}\text { İzlediğim belgeseller/animasyonlar } \\
\text { anlamamı kolaylaştırdı. }\end{array}$ & 133 & 265 & 135 & 102 & 50 & 6 & 2,52 & Kolay \\
\hline 9 & $\begin{array}{l}\text { Klasik mekaniğe yakın bir konu olduğu için } \\
\text { anlamam kolay oldu. }\end{array}$ & 47 & 190 & 227 & 178 & 47 & 2 & 2,98 & Orta \\
\hline 14 & $\begin{array}{l}\text { Konunun anlatım biçimi anlamamı } \\
\text { kolaylaştırdı. }\end{array}$ & 76 & 253 & 181 & 126 & 49 & 6 & 2,74 & Orta \\
\hline 16 & Konuyu anlamak kolay. & 64 & 178 & 202 & 169 & 67 & 11 & 3,00 & Orta \\
\hline \multirow[t]{2}{*}{21} & $\begin{array}{l}\text { Göreliliğin mantığını anladığım için kolay } \\
\text { geldi. }\end{array}$ & 66 & 244 & 190 & 151 & 37 & 3 & 2,78 & Orta \\
\hline & Ortalamala & r 78,5 & 227,7 & 189,5 & 143,7 & 46,7 & 5,0 & 2,79 & Orta \\
\hline
\end{tabular}

Tablo 4'te, konuların anlatım biçimine ilişkin maddelerden oluşan ikinci faktörün genel ortalamasına bakıldığında, bir madde hariç “Orta” düzeyde zorlanmanın olduğu söylenebilir. Ancak, maddelerin ikisi hariç tümünde "2"ye ("Kolay"a) doğru yanıtların yığıldığı söylenebilir. Buna göre, öğrencilerin genel olarak göreliliğin mantığını, felsefesini bir kez anladıktan sonra konuyu "Kolay" olarak nitelendirmeye eğilimli oldukları düşünülebilir. Öğretim tekniği ile ilgili olduğu görülen maddelerde (Madde 7) çoğunlukla güçlük düzeyinin düşük olduğu belirlenmiştir. 
Kızılcık ve Yavaş - Çukurova Üniversitesi Eğitim Fakültesi Dergisi, 46(2), 2017, 399-426

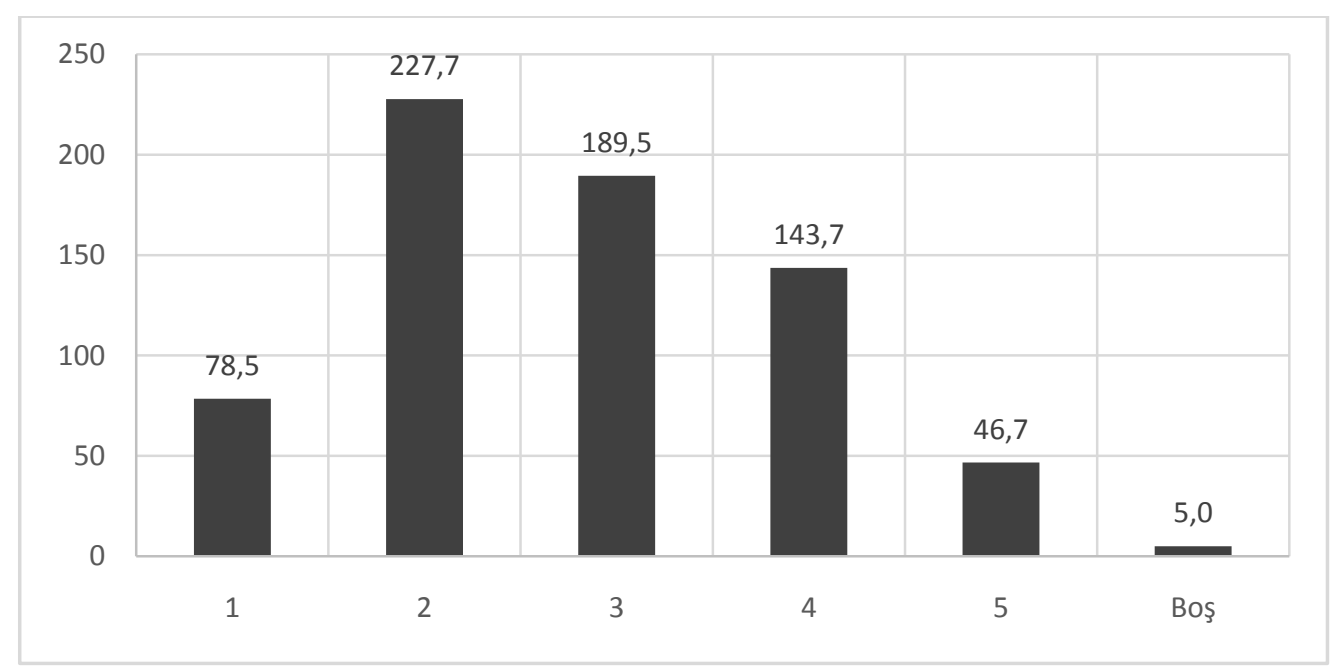

Şekil 3. İkinci faktör için ortalama zorluk derecesinin dağılımı

Şekil 3'te görüldüğü gibi, ikinci faktöre ait öğrencilerin genel zorluk derecelerinin "2"ye eğilimli olduğu görülmektedir. Yani, her ne kadar ortalamada orta düzeyde bir zorluk olduğunu gösterse de bu faktörde "Kolay"a doğru eğilimin olduğu söylenebilir.

Tablo 5.

Üçüncüfaktördeyeralanmaddelereverilenyanıtlarınfrekansdağılımı

\begin{tabular}{|c|c|c|c|c|c|c|c|c|c|}
\hline \multirow{2}{*}{$\begin{array}{l}\text { Madde } \\
\text { No }\end{array}$} & \multirow{2}{*}{ Madde } & \multicolumn{3}{|c|}{ Çok Kolay $\leftarrow$} & \multicolumn{3}{|c|}{$\rightarrow$ Çok Zor } & \multirow[b]{2}{*}{$\begin{array}{c}\text { Ort } \\
\text { Puan }\end{array}$} & \multirow[b]{2}{*}{ Aralık } \\
\hline & & 1 & 2 & 3 & 4 & 5 & Boş & & \\
\hline 17 & $\begin{array}{l}\text { Matematiksel bilgi/beceri gerektirmesi } \\
\text { anlamamı zorlaştırdı. }\end{array}$ & 81 & 227 & 181 & 153 & 47 & 2 & 2,79 & Orta \\
\hline 18 & Problemleri çözmek zor. & 52 & 205 & 163 & 209 & 57 & 5 & 3,02 & Orta \\
\hline \multirow[t]{2}{*}{22} & Birimleri çevirmekte zorlanıyorum. & 72 & 170 & 161 & 205 & 78 & 5 & 3,07 & Orta \\
\hline & Ortalan & or 68,3 & 200,7 & 168,3 & 189,0 & 60,7 & 4,0 & 2,96 & Orta \\
\hline
\end{tabular}

Tablo 5'te, öğrencilerin matematiksel zorlanmalarına ilişkin maddelerden oluşan üçüncü faktörün genel ortalamasına bakıldığında, "Orta” düzeyde zorlanmanın olduğu söylenebilir. Ancak, 22. maddeye verilen yanıtların " 4 "e doğru yığıldığı, 17. maddede ise "2"ye doğru yığıldığını görülmektedir. Söz konusu matematiksel becerilerin farklı beceriler olması buna neden olabilir. 18. maddede ise hem " 2 ", hem de "4"te yığıımanın olması, öğrenciler açısından problemlerin zor ve kolay algısında dengeli bir dağılım olduğu görülmektedir. 
Kızılcık ve Yavaş - Çukurova Üniversitesi Eğitim Fakültesi Dergisi, 46(2), 2017, 399-426

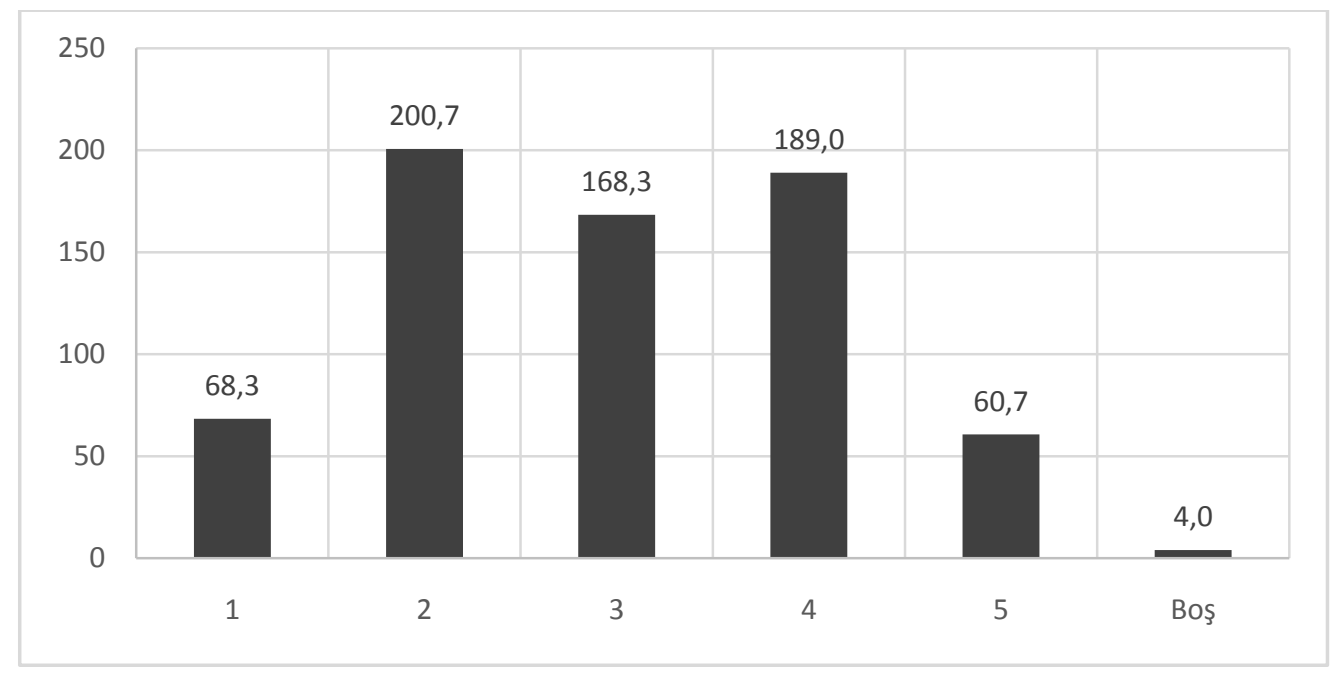

Şekil 4. Üçüncü faktör için ortalama zorluk derecesinin dağılımı

Şekil 4'te görüldüğü gibi, üçüncü faktöre ait öğrencilerin ortalama zorluk derecelerinde bir denge söz konusudur. Ancak "2"ye doğru eğilimin biraz daha baskın olduğu görülmektedir. Yani, her ne kadar ortalamada orta düzeyde bir zorluk olduğunu gösterse de bu faktörde "Kolay"a doğru eğilimin olduğu söylenebilir.

Birinci faktörde yer alan 4. maddede göreliliğin yorumlanmasının zorluğuna katılımın yüksek olduğu görülmekte. İkinci faktörde yer alan 21. maddede ise öğrenciler göreliliğin mantığının anlaşıldığında zor olmadığı görüşüne katılıyorlar. Bu iki madde birlikte ele alınırsa göreliliğin öğrenciler tarafından zor anlaşılan ancak anlaşıldığında çok da zor olmadığını gördükleri bir konu olduğunu düşündükleri sonucuna varılabilir. 15. maddede sözü edilen konunun zor olması hakkında önyargılara sahip olmaya yüksek katılımı da bu sonuca bağlayabiliriz.

Frekans bazında; birinci ve üçüncü faktörlerde yer alan ve doğrudan veya dolaylı olarak matematiksel güçlüklerle ilgili olan maddelerde (Madde 1, 19, 22) zorluk derecesinin arttığı görülmüştür. Ancak matematiksel açıdan zorlanmadığını belirten maddede (Madde 17) yoğunluk görülmektedir. Benzer biçimde, birinci ve ikinci faktörlerde yer alan; fazladan çaba, zaman ve emek harcama ile ilgili maddelerde (Madde 3,8) ve konuların zor olduğuna ilişkin önyargı ile ilgili maddede (Madde 15) yüksek güçlük düzeyinde yığılma olduğu görülmüştür.

\section{Öğrenim Düzeyi ve Cinsiyete Göre Verilerin Karşılaştırılması}

Öğrencilerin yanıtlarının cinsiyete veya öğrenim düzeyine bağlı olarak farklılık gösterip göstermediği incelenmiştir. Bu amaçla, kadın ve erkek öğrencilerle, lise öğrencilerinin ve üniversite öğrencilerinin yanıtlarının ortalamaları ayrı ayrı ele alınmıştır. 
Kızılcık ve Yavaş - Çukurova Üniversitesi Eğitim Fakültesi Dergisi, 46(2), 2017, 399-426

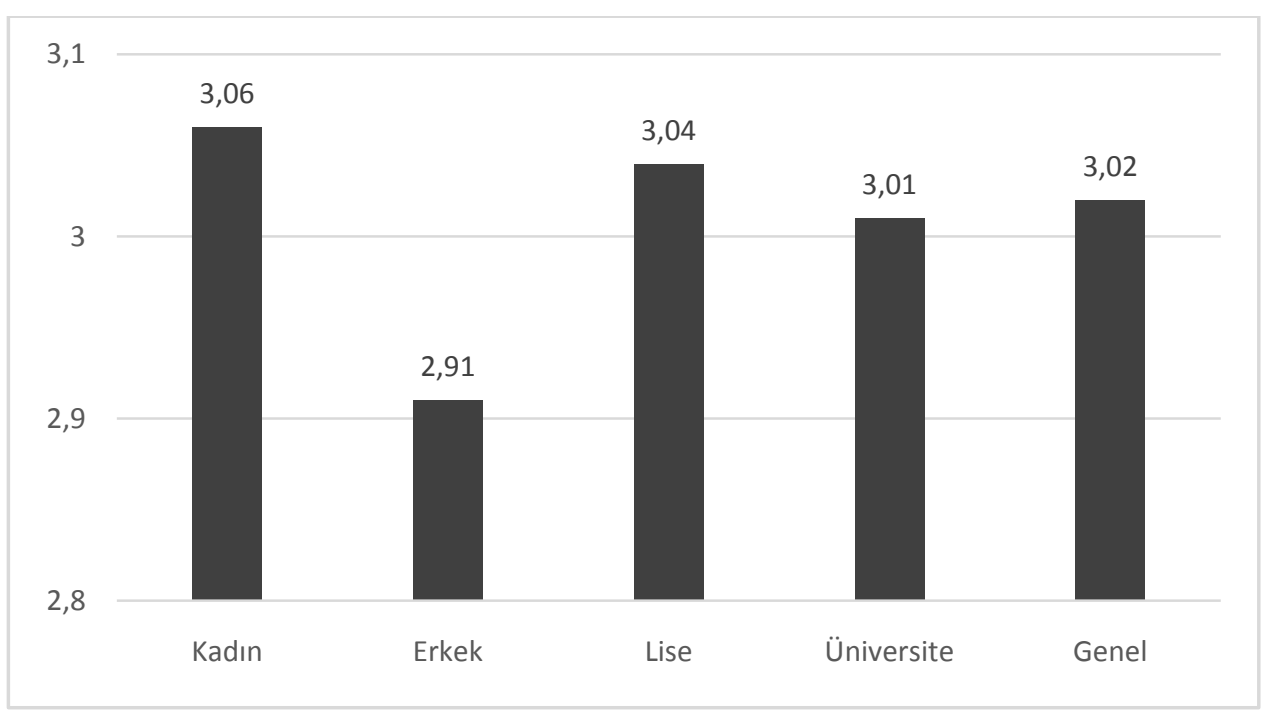

Şekil 5. Grupların ortalama puanları

Şekil 5'te görüldüğü gibi, grupların ölçeğe verdikleri yanıtların ortalamaları arasında oldukça küçük farklar vardır. Bu nedenle, verilen yanıtların faktörlere ve faktörlerde yer alan maddelere göre daha ayrıntılı bir karşılaştırma yapmak yararlı olacaktır. Kadın ve erkek öğrencilerle, lise öğrencilerinin ve üniversite öğrencilerinin yanıtlarının ortalamalarının faktörlere göre dağılımı Tablo 6'da verilmiştir.

Tablo 6.

CinsiyeteveOkulDüzeyineGöreOrtalamaPuanlar

\begin{tabular}{lcccccccccc}
\hline \multirow{2}{*}{ Faktörler } & \multicolumn{2}{c}{ Kadın } & \multicolumn{2}{c}{ Erkek } & \multicolumn{2}{c}{ Lise } & \multicolumn{2}{c}{ Üniversite } & \multicolumn{2}{c}{ Genel } \\
\cline { 2 - 12 } & Ort. & Düzey & Ort. & Düzey & Ort. & Düzey & Ort. & Düzey & Ort. & Düzey \\
\hline Birinci Faktör & 3,19 & Orta & 3,00 & Orta & 3,12 & Orta & 3,13 & Orta & 3,13 & Orta \\
\hline Ikinci Faktör & 2,80 & Orta & 2,72 & Orta & 2,86 & Orta & 2,47 & Kolay & 2,79 & Orta \\
\hline Üçüncü Faktör & 3,00 & Orta & 2,87 & Orta & 2,98 & Orta & 2,95 & Orta & 2,96 & Orta \\
\hline Genel & 3,06 & Orta & 2,91 & Orta & 3,04 & Orta & 3,01 & Orta & 3,02 & Orta \\
\hline
\end{tabular}

Tablo 6 incelendiğinde, cinsiyet ve eğitim düzeyi açısından,her bir faktör için biri dışında tüm zorluk düzeylerinin "orta" düzey aralığında olduğu görülmektedir. Yalnızca ikinci faktörde üniversite öğrencilerinin ortalaması "kolay" düzey aralığında çıkmıştır. Bu da göstermektedir ki, üniversite öğrencileri, konunun öğretim yöntemleri ile ilgili lise öğrencilerine göre daha az zorluk yaşamaktadır.

Tüm ölçek maddeleri incelendiğinde, lise ve üniversite öğrencilerinin yanıtları arasında anlamlı fark olup olmadığı t testi ile belirlenmiştir. Yapılan t testi sonuçlarına göre, zorlanma nedeni olarak birinci faktörde yer alan Madde 2 ve ikinci faktörde yer alan Madde 7 ve 14'te lise öğrencilerinde, birinci faktörde yer alan Madde 13'te ise üniversite öğrencilerinde anlamlı bir fark görülmüştür. Anlamlılık değeri 0,05'in altında olan söz konusu maddelerin $t$ değeri ve buna göre anlamlılık değeri şöyledir: 2 . madde $(2,126 ; p: 0,034)$, 7. madde $(2,496 ; p: 0,013)$, 13 . madde $(-2,320 ; p: 0,021), 14$. madde $(2,044 ; p$ : 0,042). Yani, öğretim teknikleri ile ilgili olarak üniversite öğrencilerinin daha düşük düzeyde zorlanma yaşamaktadır. Buna karşın, üniversite öğrencilerinin lise öğrencilerine göre anlamlı olarak konuları daha soyut olarak nitelendirdiği anlaşılmaktadır.

Cinsiyete göre $\mathrm{t}$ testi sonuçları bazı maddelerde kadınların erkeklere nazaran anlamlı bir biçimde daha fazla güçlük çektiğini göstermektedir. Bunlar; birinci faktörde yer alan Madde 1, 4, 6, 8, 11, 13, 23; 
ikinci faktörde yer alan Madde 16 ve üçüncü faktörde yer alan Madde 22'dir. Anlamlılık değeri 0,05'in altında olan söz konusu maddelerin $t$ değeri ve buna göre anlamlılık değeri şöyledir: 1 . madde ( $t$ : 2,275; $\mathrm{p}: 0,023)$, 4. madde (t: 2,855; p: 0,005), 6. madde (t: 2,936; $\mathrm{p}: 0,004), 18$. madde (t: 2,064; $\mathrm{p:} 0,040), 11$. madde (t: 2,919; $\mathrm{p}: 0,004), 13$. madde (t: 2,988; $\mathrm{p}: 0,003), 16$. madde (t: 2,$110 ; \mathrm{p}: 0,036), 22$. madde (t: 2,296; p: 0,022), 23. madde (t: 4,978; p: 0,000). Buna göre, matematiksel güçlükler ve klasik fizik-modern fizik paradigma değişiminden ileri gelen algısal güçlüklerle ilgili maddelerde kadınların daha çok zorlandıkları belirlenmiştir.

\section{Sonuç ve Tartışma}

Özel göreliliği derslerinde görmüş olan lise ve üniversite öğrencilerinin özel görelilik zorluk nedenleri ölçeğine verdikleri yanıtlardan elde edilen bulgular, öğrencilerin bu konuyu zor olduğu kadar kolay olduğunu da düşündüklerini göstermektedir. Özele inildiğinde, her bir maddede yer alan ifadenin zor veya kolay olarak öğrenciler tarafından nitelendirilmesi; cinsiyete, öğrenim düzeyine bağlı olabileceği gibi, bunlardan bağımsız olarak da değişebildiği belirlenmiştir.

Lise öğrencilerinin bulguları ile üniversite öğrencilerinin bulguları karşılaştırıldığında ölçek puan ortalamaları açısından belirgin bir fark görülmemektedir. Ancak her madde için zorluklar, lise ve üniversite öğrencileri için ayrı olarak karşılaştırıldığında lise öğrencilerinin konunun anlatım biçimi açısından ve fazladan çaba ve zaman harcamak gerektirmesi bakımından daha çok zorlandıkları görülmüştür. Bunun sebebinin liselerde konunun daha dar kapsamlı olması bakımından öğretim sırasında farklı öğretim yöntemlerinin kullanılmamış olabileceğini düşünmekteyiz. Bu duruma açıklık getirebilmek için ek bir araştırma ile göreliliğin öğretiminde kullanılan öğretim yöntemleri araştırılabilir. Çünkü özel görelilik sadece matematiksel bir şekilde öğretilirse, öğrenciler özel göreliliğin kavramlarının klasik göreli kavramlardan ne farkı olduğunu anlayamamaktadır (Arriassecq ve Greca, 2012). Alanyazında görelilik teorisinin öğretiminde öğrencilerin çeşitli kavramsal zorluklara sahip olduğu belirtilmektedir (Dimitriadi ve Halkia, 2012; Korkmaz ve diğerleri, 2016; Sherr ve diğerleri, 2001; Sherr, 2007, Villani ve Pacca, 1987;). Bu zorlukların aşılmasında alanyazında yapılan öneriler genellikle öğretim yöntemlerinin çeşitliliğine vurgu yapmaktadır. Örneğin düşünce deneyleri ve paradoksların kullanımı (Cornier ve Steinberg, 2010; Cacioppo ve Gangopadhyaya, 2012; Velentzas ve Halkia, 2013), bilgisayar simülasyonları ve oyunları (Kraus, 2008; Wegener ve diğerleri, 2012; Savage ve diğerleri, 2007; Carr ve Bossomaier, 2011), bazı deneylerin kullanımı (Singh ve Hedgeland, 2015) özel göreliliğin öğretimi için önerilmektedir.

Konuya yönelik algı faktörü ile ilgili bulgular, öğrencilerin klasik fizik ile görelilik arasındaki farkları anlama konusundaki zorlanma ifadesine katıldıklarını göstermektedir. Ayrıca klasik fizikten modern fiziğe geçiş ile ilgili paradigma değişiminin ortaya çıkardığı zorluklar ile ilgili maddelere verilen yanıtların yüksek zorlanma düzeyinde yığılma olduğu bulgulardan anlaşılmaktadır. Özellikle kadın öğrencilerin, erkeklere oranla bu konuda daha fazla zorlandıkları dikkat çekmektedir. Bunun nedenleri, ayrıntılı olarak araştırılabilir. Alanyazına göre, öğrenciler görelilik ile ilgili sorulara cevap verirken klasik fizik kullanma eğilimi göstermektedir (Turgut ve diğerleri, 2013; Pietrocola ve Zylberztajn, 1999). Öğrenciler özel görelilikle ilgili problemlerin çözümünü yapsalar dahi göreliliğin ana kavramlarının anlaşıması sürecinde klasik düşünme yollarını değiştirmede zorluk yaşamaktadır (Arriassecq ve Greca, 2012). Sherr (2007) bu zorluğa günlük yaşamda edindiğimiz tecrübelerin sebep olduğunu belirtmektedir. Ayrıca bu çalışmanın bulguları öğrencilerin klasik fizik konularında eksiklikleri olması fikrine katılma oranlarının yüksek olduğunu göstermektedir. Benzer sonuçlar Selçuk'un (2011) çalışmasında da görülmektedir. Sherr ve diğerleri (2001) öğrencilerin özel görelilikte başarısızlıklarının altında yatan sebebin daha temel konuları anlamalarındaki eksiklikler olduğunu belirtmiştir.

Öğrencilerin özel görelilikte zorlanma nedenlerinden biri de matematiksel zorluklar olduğu araştırma bulguları sonucunda görülmektedir. Üçüncü faktörü oluşturan matematiksel zorluklarla ilgili maddelerde öğrencilerin matematiksel zorluk yaşadıkları anlaşılmaktadır. Ancak konunun matematiğinin zor olmadığını düşünenlerin sayısı da oldukça fazladır, hatta öğrencilerin çoğu 17. maddede matematiksel beceriler bakımından zorlandıkları fikrine katılmamıştır. Bu duruma, lise ve üniversite öğrencileri 
arasında anlamlı fark olması bulgusu da eklendiğinde, lise ve üniversitede öğretilen konuların kapsamı ve matematiksel içeriğinin farklı olmasının sebep olduğu yorumu yapılabilir. Ek olarak, cinsiyete göre matematiksel zorluklar içeren ifadelerde anlamlı fark bulunmuştur. Kadınların erkeklere göre matematiksel becerileri içeren maddelerde daha çok zorlandıklarını belirtmişlerdir. Bunun nedenlerinin araştırılacağı çalışmalar yapıımalıdır. Alanyazında öğrencilerin görelilik teorisi ile ilgili matematiksel zorluklara dikkat çekilmektedir (Didiş Körhasan ve Özcan, 2015; Turgut ve diğerleri, 2013; Ogborn, 2005). Angell ve diğerleri (2004) fizik dersi hakkında öğrenci ve öğretmen görüşlerini araştırdıkları çalışmasının sonuçlarında öğrencilerin matematiği bir sorun olarak görmediklerini ancak öğretmenlerin öğrencilerin matematik becerilerindeki eksikliklerden yakındıklarını belirtmektedir. Yine bu çalışmanın sonuçları öğrencilerin görelilik konusunu ilginç bulduklarını göstermektedir. Görelilik teorisinin öğretiminde matematiksel içeriğin azaltılmasını ve konunun ana kavramlarını öğrencilerin anlayabileceği tarzda düzenlemenin daha etkili olacağını düşünmekteyiz. Bununla ilgili olarak Velentzas ve Halkia'nın (2013) düşünce deneylerinin görelilik teorisinin öğretiminde kullanılmasının hikaye tarzında ve az matematik içermesi bakımından avantajlarına dikkat çekmiştir. Arriassecq ve Greca (2007) da özel göreliliğin öğretiminde kavramsal olarak uygun ve motive edici materyallerin hazırlanmasının öğrencilerin anlamlı öğrenmesini sağlamada etkili olacağını belirtmiştir. 


\section{References}

Al-Khalili, J. (2003). Time travel: separating science fact from science fiction. Physics Education, 38(1), 14-19.

Angell, C., Guttersrud, Ø., Henriksen, E. K. velsnes, A. (2004). Physics: Frightful, but fun pupils' and teachers' views of physics and physics teaching. Science Education, 88(5), 683-706.

Arriassecq, I. veGreca, I. M. (2007). Approaches to the Teaching of Special Relativity Theory in High School and University Textbooks of Argentina. Science \& Education, 16, 65-86.

Arriassecq, I. veGreca, I. M. (2012). A teaching-learning sequence for the special relativity theory at high school level historically and epistemologically contextualized. Science \& Education, 21, 827-851.

Belloni, M., Christian, W. veDancy, M.H. (2004). Teaching Special Relativity Using Physlets. The Physics Teacher, 42, 284-290.

Burke, J. R. ve Strode, F. J. (1991). Classroom exercises with the Terrell. American Journal of Physics, 59(10), 912-915.

Cacioppo, R. veGangopadhyaya, A. (2012). Barn and pole paradox: revisited. Physics Education, 47(5), 563-567.

Carr, D. veBossomaier, T. (2011). Relativity in a rock field: A study of physics learning with a computer game. Australasian Journal of Educational Technology, 27(6), 1042-1067.

Cornier, S. ve Steinberg, R. (2010). The Twin Twin Paradox: Exploring Student Approaches to Understanding Relativistic Concepts. The Physics Teacher, 48, 598-601.

Demir, N. veAkarsu, B. (2014). Modern FizikKonularileilgiliKavramTestiGeliştirilmesiveUygulanması: Modern FizikKavramTesti (MKFT). Journal of European Education, 4(2), 39-51.

DidişKörhasan, N. veÖzcan, Ö. (2015). Examination of the variation in students' problem solving approaches due to the use of mathematical models in Doppler Effect. HacettepeÜniversitesiEğitimFakültesiDergisi (H. U. Journal of Education), 30(3), 87-101.

Diessler, R. J. (2005). The appearance, apparent speed, and removal of optical effects for relativistically moving objects. American Journal of Physics, 73, 663-669.

Dimitriadi, K. veHalkia, K. (2012). Secondary students' understanding of basic ideas of special relativity. International Journal of Science Education, 34(16), 2565-2582.

Gim, J. (2016). Special Theory of Relativity in South Korean High School Textbooks and New Teaching Guidelines. Sciecne\& Education, 25, 575-610.

Guisasola, J., Solbes, J., Barragues, J., Morentin, M. ve Moreno, A. (2009). Students' Understanding of the Special Theory of Relativity and Design for a Guided Visit to a Science Museum. International Journal of Science Education, 31(15), 2085-2104.

Ireson, G. (1996). Relativity at A-level: A looking glass approach. Physics Education, 31(65), 356-361.

Korkmaz, S.D., Aybek, E.C. veÖrücü, M. (2016). Special relativity theorem and Pythagoras's magic. Physics Education, 51, 1-8.

Kortemeyer, G., Fish, J., Hacker, J., Kienle, J., Kobylarek, A., Sigler, M., Wierenga, B., Cheu, R., Kim, E., Sherin, Z., Sidhu, S. ve Tan, P. (2013). Seeing and experiencing relativity - A new tool for teaching? The Physics Teacher, 51, 460-461.

Kraus, U. (2008). First-person visualizations of the special and general theory of relativity. European Journal of Physics, 29, 1-13.

MEB

(2007).

OrtaöğretimFizikDersiÖğretimProgramı, <http://www.modernfizikyayinlari.com/uploads/downloads/1322910156.pdf>Erişimtarihi: 10.03.2017. 
MEB (2013). OrtaöğretimFizikDersiöğretimProgramı, <http://mebk12.meb.gov.tr/meb_iys_dosyalar/31/01/972850/dosyalar/2013_07/05032334_fizik_91 2.pdf $>$ Erişimtarihi: 10.03.2017.

Ogborn, J. (2005). Introducing relativity: less may be more. Physics Education, 40(3), 213-222.

Özcan, Ö. (2011). Fiziköğretmenadaylarınınözelgörelilikkuramıileilgili problem çözmeyaklaşımları. HacettepeÜniversitesiEğitimFakültesiDergisi, 40, 310-320.

Penrose, R. (1959). The apparent shape of a relativistically moving sphere. Proc. Cambridge Philos. Soc., 55, 137-139.

Pietrocola, M. vezylberztajn, A. (1999). The use of the Principle of Relativity in the interpretation of phenomena by undergraduate physics students. International Journal of Science Education, 21(3), 261-276.

Savage, C.M., Searle, A. veMcCalman, L. (2007). Real Time Relativity: Exploratory learning of special relativity. American Journal of Physics, 75, 791-798.

Scherr, R.E., Shaffer, P.S. veVokos, S. (2001). Student understanding of time in special relativity: Simultaneity and reference frames. American Journal of Physics, 69, S24-S35.

Scherr, R.E., Shaffer, P.S. veVokos, S. (2002). The challenge of changing deeply held student beliefs about the relativity of simultaneity. American Journal of Physics, 70(12), 1238-1248.

SeçkinKapucu, M. (2016). An Examination of the Documentary Film "Einstein and Eddington" in terms of Nature of Science Themes, Philosophical Movements, and Concepts. International Journal of Progressive Education, 12(2), 34-46.

Selçuk, G.S. (2011). Addressing pre-service teachers' understandings and difficulties with some core concepts in the special theory of relativity. European Journal of Physics, 32, 1-13.

Sherin, Z.W., Cheu, R. Tan, P. veKortemeyer, G. (2016). Visualizing relativity: The OpenRelativity Project. American Journal of Physics, 84, 369-374.

Sherr, R. (2007). Modeling student thinking: An example from special relativity. American Journal of Physics, 75, 272.

Singh, P. veHedgeland, H. (2015). Special relativity in the school laboratory: a simple apparatus for cosmic-ray muon detection. Physics Education, 50(3), 317-323.

Smith, G. S. (2011). Visualizing special relativity: the field of an electric dipole moving at relativistic speed. European Journal of Physics, 32, 695-710.

Terrell, J. (1959). "The invisibility of the Lorentz contraction," Phys. Rev. 116, 1041-1045.

Turgut, U., Gurbuz, F., Salar, R. veToman, U. (2013). The viewpoints of physics teacher candidates towards the concepts in special theory of relativity and their evaluation designs. International Journal of Academic Research, 5(4), 481-489.

ÜnlüYavaş, P. \&Kızıııık, H. Ş. (2016). Pre-Service Physics Teachers' Difficulties in Understanding Special Relativity Topics. European Journal of Physics Education, 7(1), 1309-7202.

Velentzas, A. veHalkia, K. (2013). The use of thought experiments in teaching physics to upper secondary-level students: Two examples from the theory of relativity. International Journal of Science Education, 35(18), 3026-3049.

Villani, A. veArruda, S.M. (1998). Special theory of relativity, conceptual change and history of science. Science \& Education, 7, 85-100.

Wegener, M., McIntyre, T. J., McGrath, D., Savage, C. M. ve Williamson, M. (2012). Developing a virtual physics World. Australasian Journal of Educational Technology, 28(special issue, 3), 504-521.

Weisskopf, V. F. (1960). The visual appearance of rapidly moving objects, Phys. Today 13(9), 24-27. 
Kızılcık ve Yavaş - Çukurova Üniversitesi Eğitim Fakültesi Dergisi, 46(2), 2017, 399-426

Yıldız, A. (2012). Prospective Teachers' Comprehension Levels of Special Relativity Theory and the Effect of Writing for Learning on Achievement. Australian Journal of Teacher Education, 37(12), 15-28. 